\title{
A Methodology for Paradigm Shift to Explain Sustainable University
}

Mansoor Shahvali ${ }^{1}$ Professor, Agricultural Education and Extension, Shiraz University, Iran.

Seyedeh Fatemeh Moezzi ${ }^{2}$ Ph.D. Student, Agricultural Education and Extension, Shiraz University, Iran (Author Corresponding).

Rahmatollah Marzooghi ${ }^{3}$ Professor, Agricultural Education and Extension, Shiraz University, Iran.

\begin{abstract}
The sustainable university concept is rooted in prevalent paradigms pertained to economic, social and environmental development, which all focus on systemic thought and rationality; besides, they tend to discover and solve problems by applying an interdisciplinary approach. However, the epistemic component is what these paradigms have ignored. The purpose of this study is to explain a methodology for the shift from current paradigms to spiritual ones for sustainable higher education. To reach this end, meta-synthesis method was applied, based on which 46 qualitative researches covering sustainability domain were gathered and their findings were analyzed and evaluated. The viewpoints of these studies were put together and synthesized to introduce a more comprehensive substitute. Results show that the dynamic spiritual paradigm based on wisdom and objective knowledge is in line with the divine wisdom of Iranian universities
\end{abstract}

Keywords: Higher Education, Sustainable University, Meta-synthesis Methodology, Spiritual Paradigm, Wisdom.

1. Shahvali@shirazu.ac.ir

2.moezzi@shirazu.ac.ir

3.rmarzoghi@rose.shirazu.ac.ir 


\section{مقام}

تلاشهاى توسعه پايدار در دو دها اخير از دستاوردهاى مههم جامعه بشرى است. اما در اين

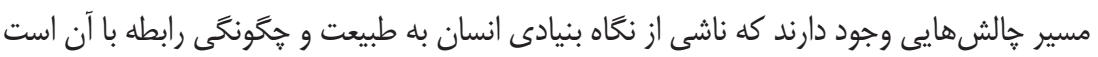

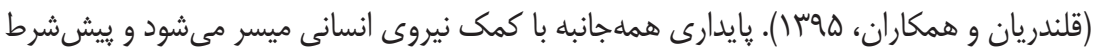
آن، سرمايه كذارى براى آموزش آنهاست. با وجود تلاشهاى گَسترده نظامهاى بين المللى و ملّى

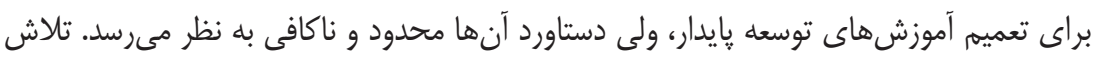
دانشگاهها براى تحقق پايدارى نشان مىدهد كه دستيابى به افقهاى بلند ابعاد پايدارى، نيازمند اصلاح آموزههاى نخرشى، بينشى، و دانشى انسانها نسبت به سرنوشت و محيط است. يس ضرورى است كه انخارهها و راهبردهاى آموزشى از اساس متحول شوند (فراستخواه، 91؟1). در اين راستا، يارادايم آموزش عالى كشاورزى و منابع طبيعى نيازمند رويكردى فرارشتهاى است كه هـ اسه با ترويج بينش معرفتى بر اساس اسناد بالادستى كشور براى حل مسائل حال و آينده عمل كند.

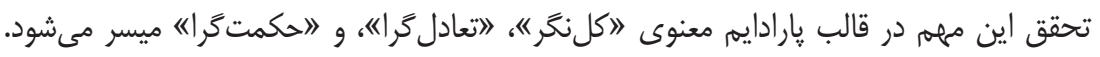
براى اين منظور، تبيين يارادايم معنوى براى دانشخاه پايدار كه به سبك زندگى دينى منجر شود،

$$
\text { هدف كلى اين يثوهش است. }
$$

بررسىهاى انجامشده بر مدلهاى مطرح در دانشگاه يايدار توسط ادبيات ييشين نشان مىدهد

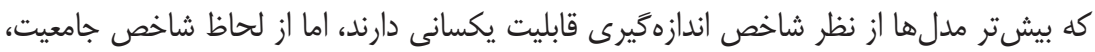

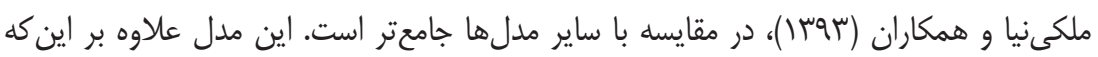
بيشتر شاخصهاى مدلهاى ديخر را از جنبههاى متعدد يوشش مىدهد، به مولفه نظام تامين

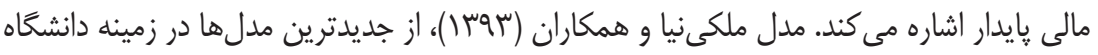
پايدار است، ولى نياز است كه به اين مدل شاخصهايى اضافه شود. امروزه نقش فرهنَ در اسناد بينالمللى توسعه پايدار مورد تاكيد ويزه است. يِ گَنجاندن اين بُعد از يايدارى در كنار ديخر ابعاد

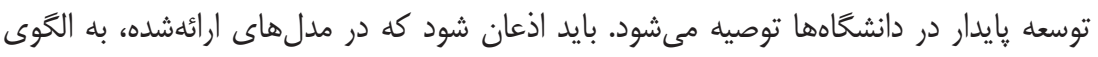
ايرانى ـ اسلامى ييشرفت و فرهنگ غنى ايران اسلامى توجه نشده است. بررسى يُوهشهاى

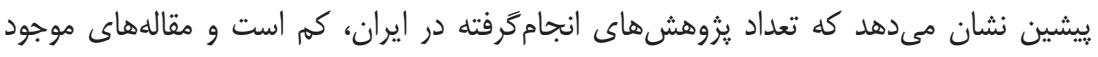

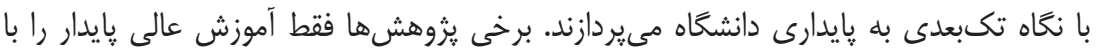


يارادايم رايج علمَرا بررسى مى كنند و تعداد اندكى با در نظركَرفتن شرايط بومى، در ارائه الكوى

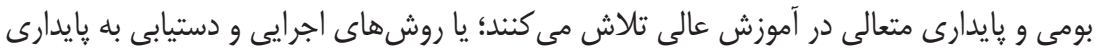

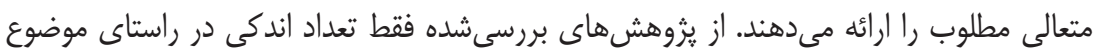

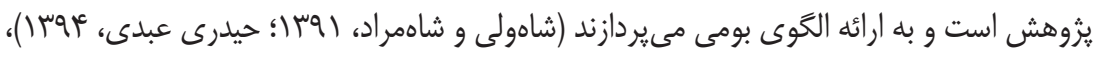

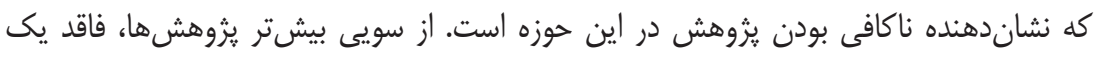

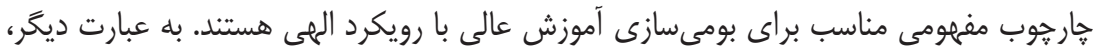

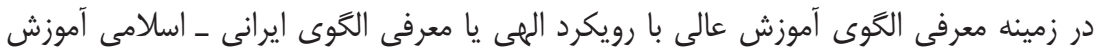

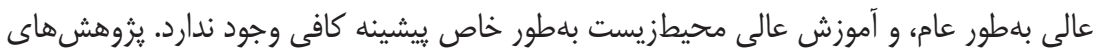

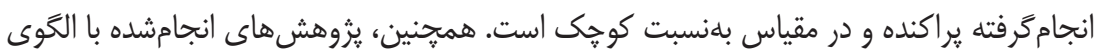

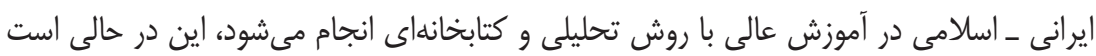

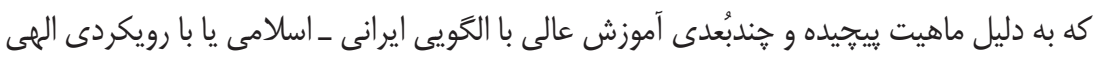

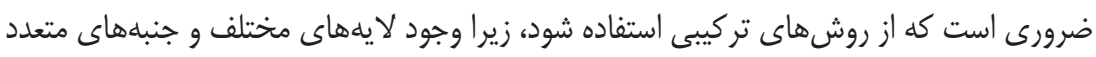

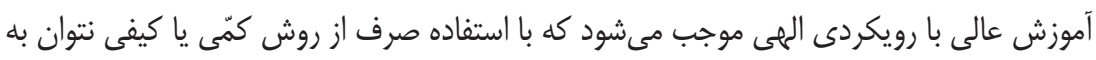

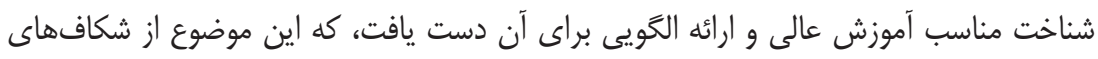
موجود در ادبيات يثوهش است.

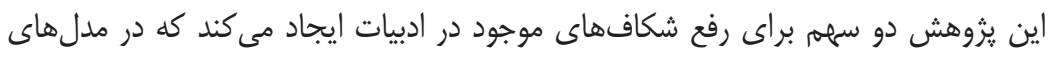

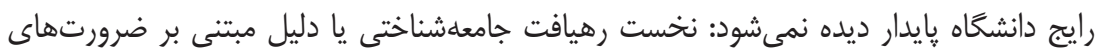

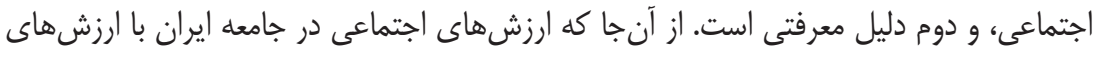

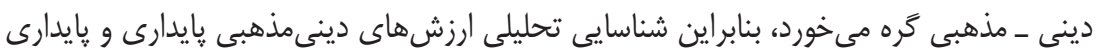

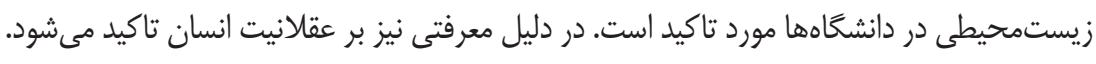

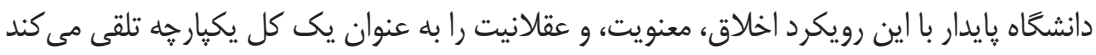

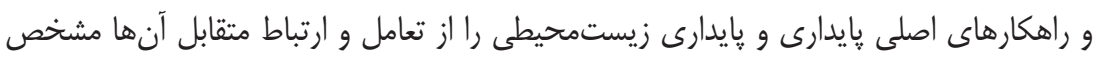

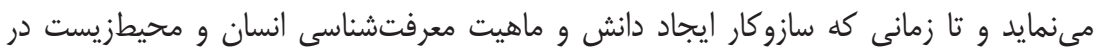

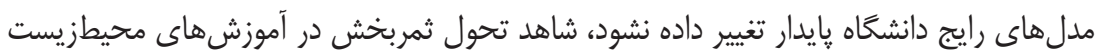

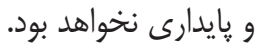




\section{مبانى نظرى يزوهش}

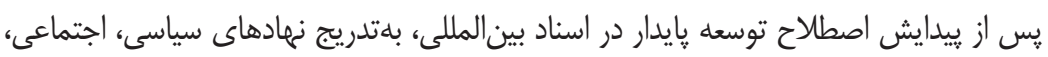

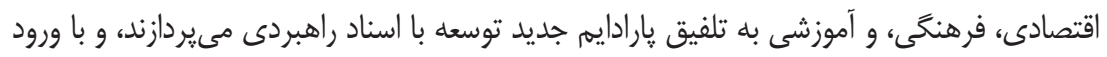

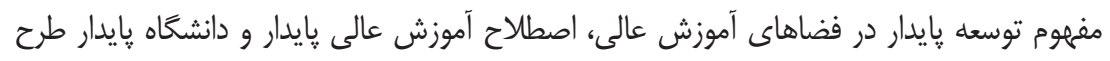

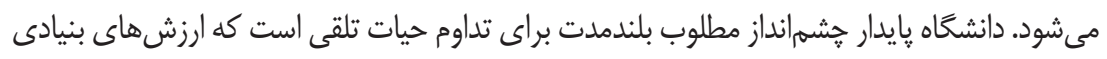

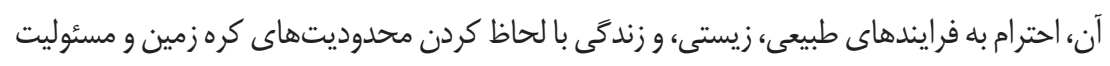

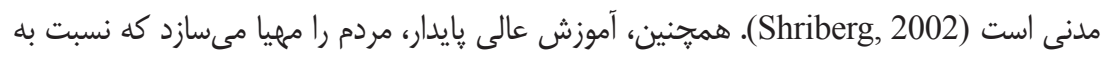

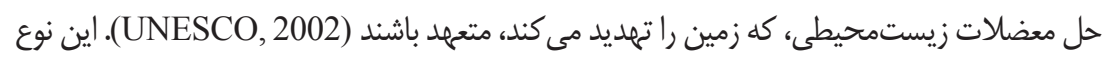

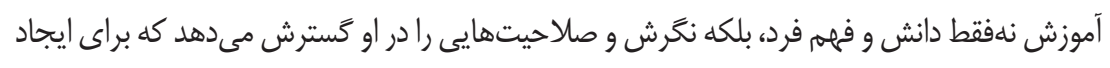

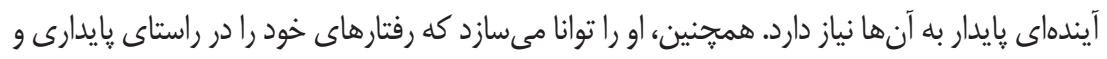

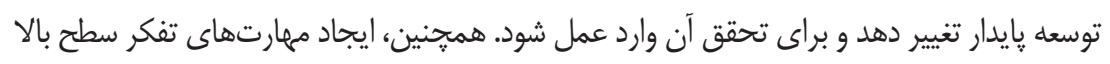

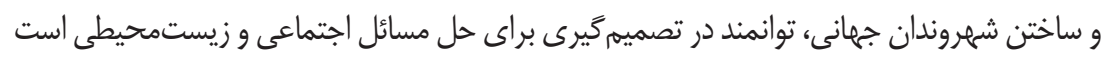

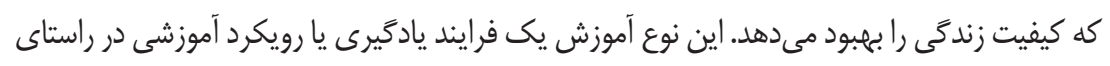

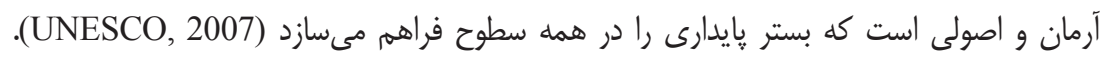

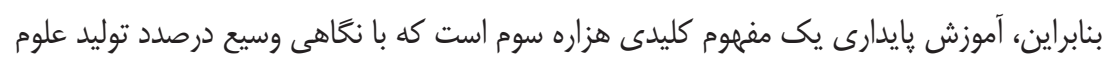

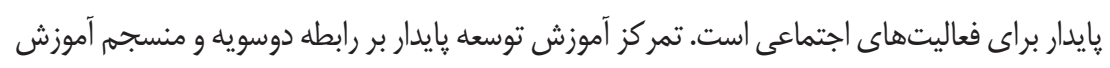

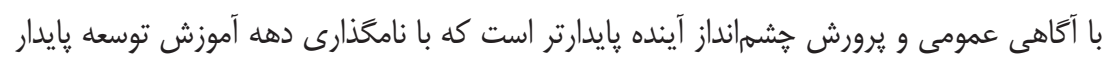

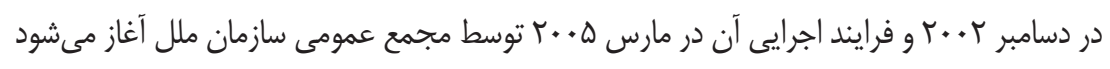

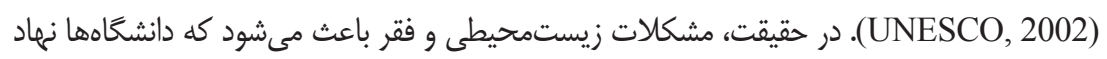

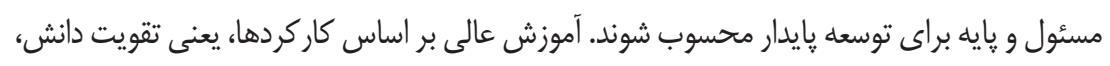

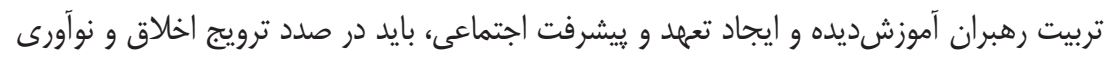

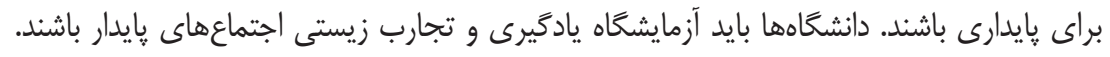

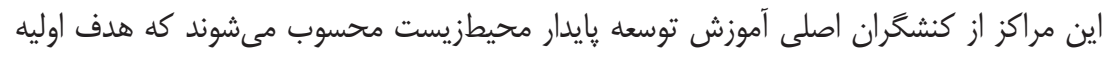

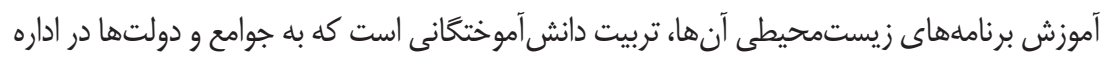

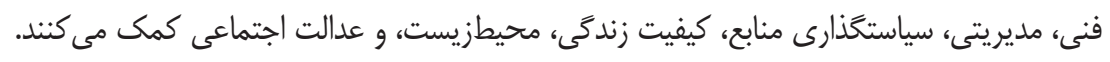

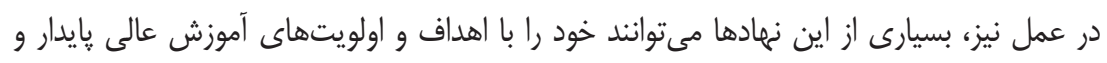

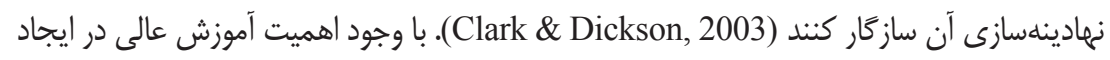


يايدارى، ولى نتايج يزوهشها در كشورى مانند ايران نشان مىدهد كه وضعيت قابليتهاى آموزش

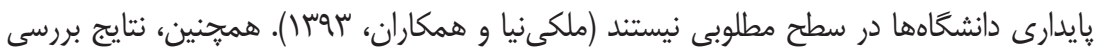

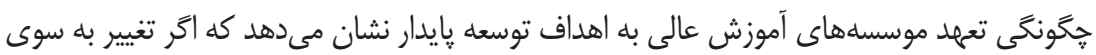
توسعه קِايدار و بايدارى است، نيازمند شكل گَيرى درى بهترى از موسسههاى آموزش عالى است؛

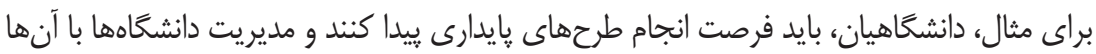
همكارى داشته باشند (Godemann et al., 2014). شيل و همكاران' (عا. +r)، كزارش مى كنند كه

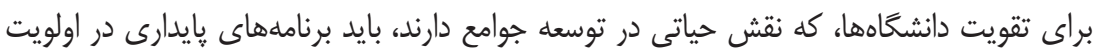

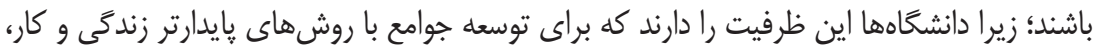
نقش ييشرويى ايفا كنند. آنجه تحت عنوان بايدارى انجام مى گيرد نشان مىدهد كه فعالان دانشخاه بايدار در كشورهاى توسعهيافته تلاش مى كنند با افزايش فضاى سبز، محيط دانشخاه رابه محيط دوستدار طبيعت ييش برند و همه فراكيران را نيز به سمت حفاظت از محيطزيست و مشار كت در يروزههاى محيطزيستى تشويق

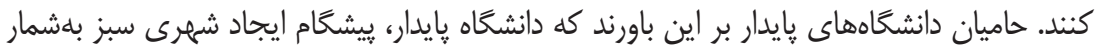
معرود و در نهايت كشور و جهانى سبز را به ارمغان مىآورد (Petratos \& Damaskou, 2015).

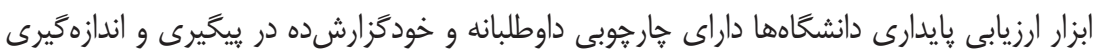
ييشرفت در تبديل به دانشگاه پايدار است. برخى ابزارهاى ارزيابى پايدارى در داخل كشور داراراى

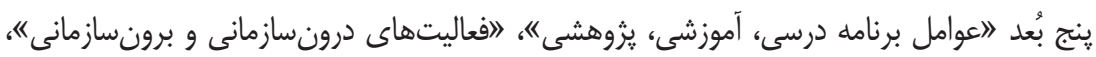

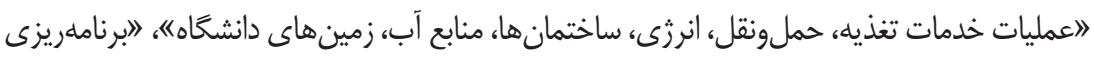

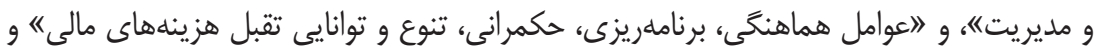

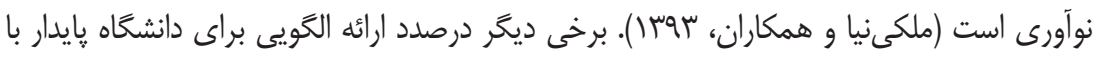

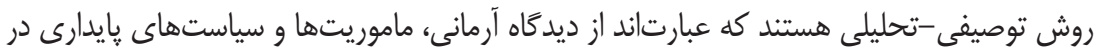

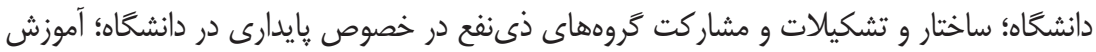

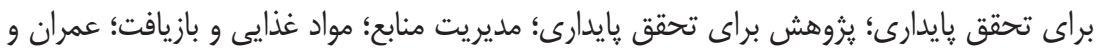

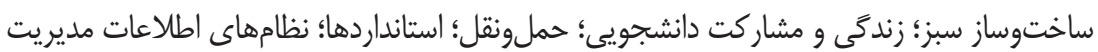
توسعه קايدار در دانشگاه؛ آزادى علمى؛ مسئوليتهاى روشن؛ و ياسخكَويى است (صادقى و همكاران،

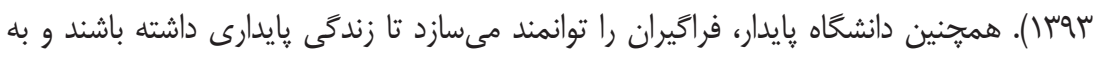

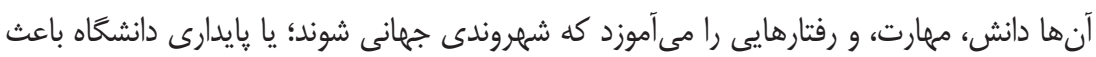

1. Shiel et al. 
صرفهجويى مصرف انرزى مى شود و بلطور همزمان، به بهبود بهيداشت، رفاه عاطفى و جسمانى

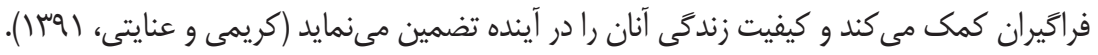

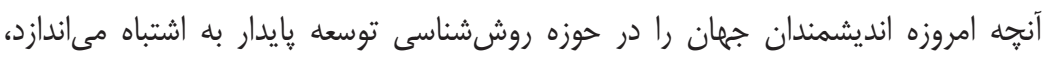

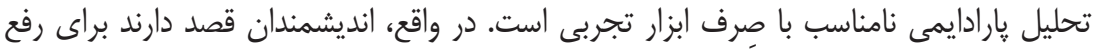

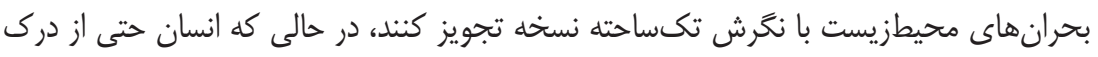

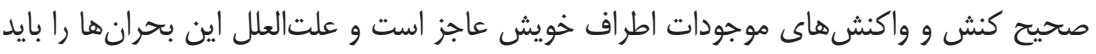

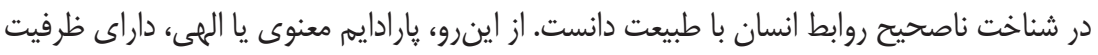

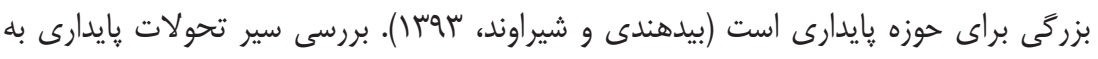

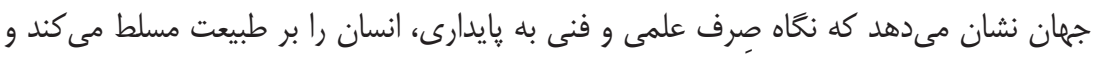

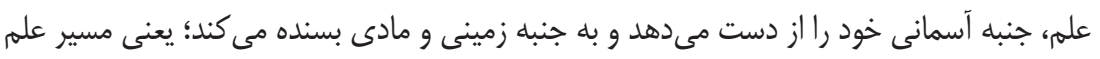

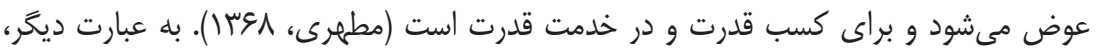

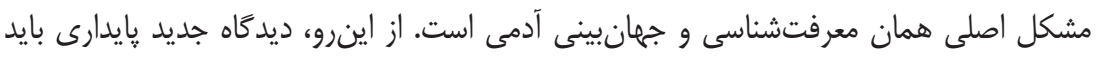

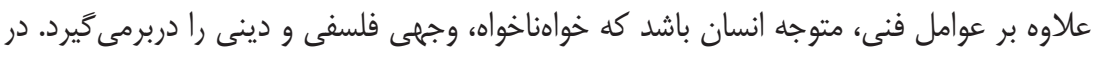

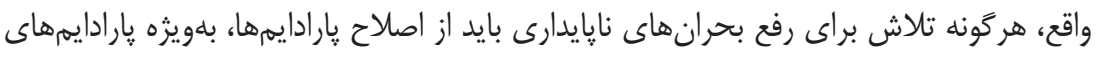

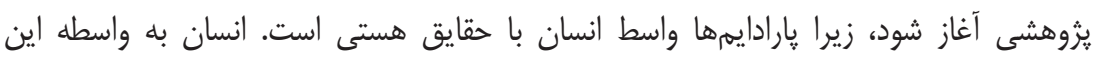

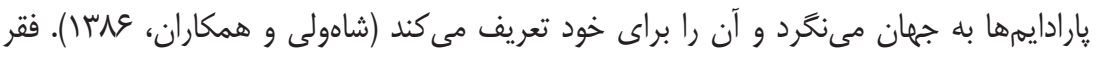

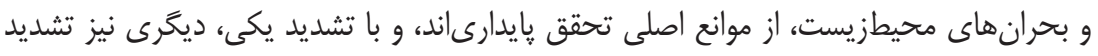

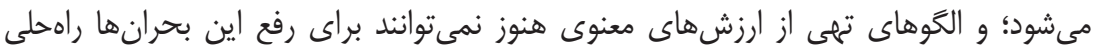

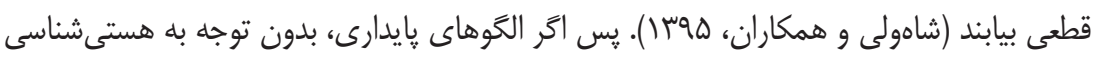

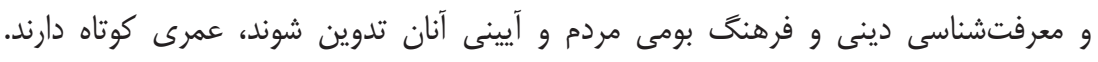
$\int^{2}$

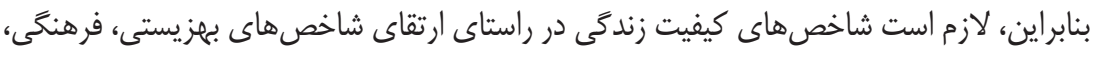

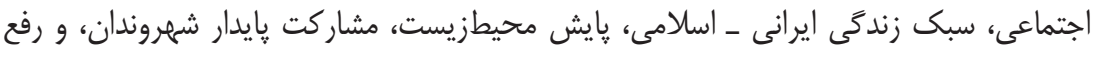

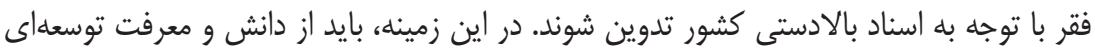

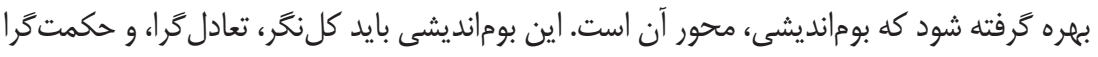
باشد (عنبرى، أوح||)، تا دانشخاه بايدار شكل كَيرد. 


\section{روششناسى بزوهش}

رشد يزوهشها در حوزهاى مختلف دانش موجب مىشود كه مقوله تركيب يزوهشهاى ييشين به شيوه نظاممند به موضوعى خاص براى ايجاد درك بيشتر ادبيات كسترش يابد (ازكيا و توكلى، همب(ا). براى سنتز يزوهشهاى كيفى، عناوين فراتركيب، فراتحليل كيفى، فراتركيب كيفى، و فراتر كيب تفسيرى استفاده مىشود. اما وازه غالب براى اين منظور، فراتركيب كيفى است (Timulak, 2009). در حال حاضر روشهاى فراتحليل كيفى، در جامعهشناسى، انسانشناسى،

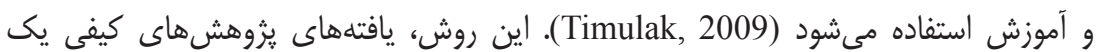

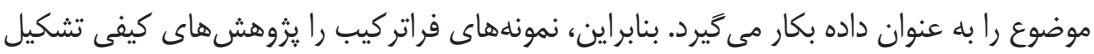
مىدهند كه محقق بر اساس يرسش يزوهش، آنها را بررسى مى كند (Sandelowski, 2008). وجه مشتر ك روشهاى فراتركيب، تفسيرى جديد از موضوع است (Finfgeld-Connett, 2006)،

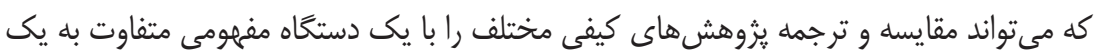
دانش جامع تبديل نمايد (Bergdahl, 2019). اين تفاسير در حقيقت برداشتها و استتناجهايى

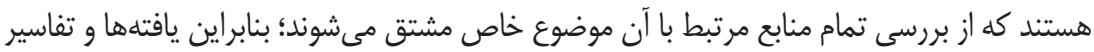
جديد در هيج يك از منابع اوليه يافت نمىشود. اين تفاسير اجازه مىدهند كه نشان داده شود وجه مشتر ك موضوع يزوهش و جنبههاى متفاوت آن كدام هستند (Aguirre \& Bolton, 2014). بلهور خلاصه، روش فراتركيب با اين هدف در اين يزوهش بكار مىرود كه يك شناخت جامعتر و درى

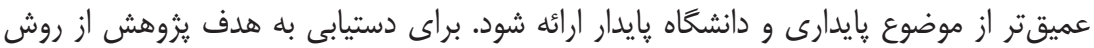

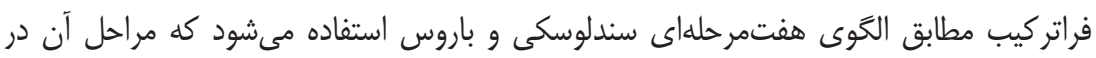
جدول (ا) ارائه مىشود (Sandelowski \& Barroso, 2007):

جدول ا: مراحل روش فراتر كيب

\begin{tabular}{|c|c|c|c|c|c|}
\hline مقاله ماى تعداد & نداد مقاله دادها & بازه زمانى & در كاه جستجو & جستجو در & كليدوازمهاى منتخب \\
\hline 49 & $V \Delta$ & $1 \% V \lambda-1$ rqV & $\begin{array}{l}\text { Civilica } \\
\text { Magiran } \\
\text { Irandoc } \\
\text { Noormags } \\
\text { SID }\end{array}$ & 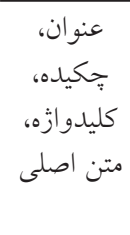 & 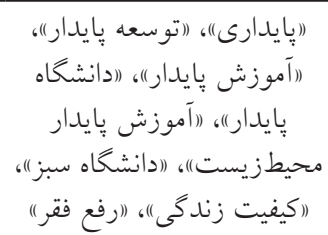 \\
\hline
\end{tabular}


در مرحله انتخاب منابع واجد شرايط فراتركيب، از يزوهشهاى كيفى منتشرشده در بازه زمانى من

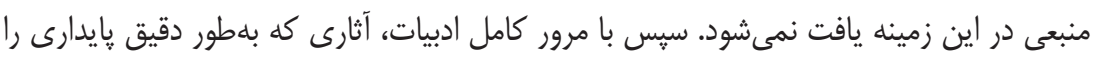

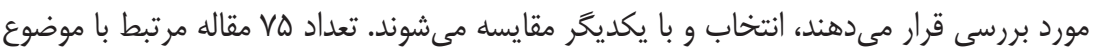

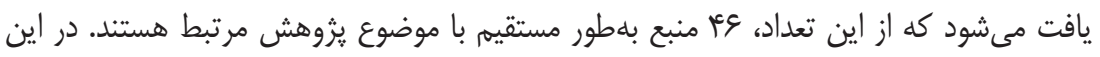
يزروهش، براى بررسى كيفيت و تحليل كيفى متون مورد نظر از شاخص بليكى استفاده مى شود كه

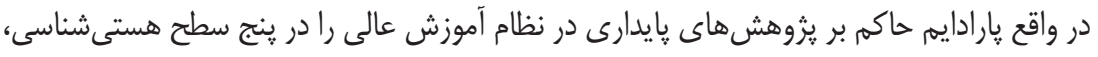

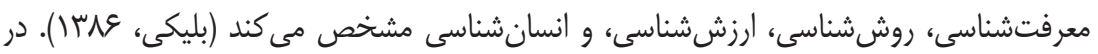

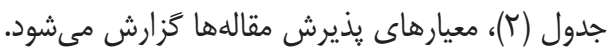

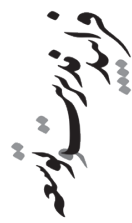

\begin{tabular}{|c|c|}
\hline 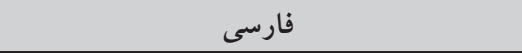 & زبان \\
\hline 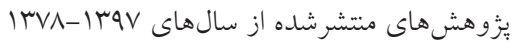 & 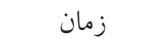 \\
\hline روشهاى كيفى جمع آورى داده و تحليل آن & روش بيزوهش \\
\hline مقالههاى منتشرشده در نشريهها و كنفر انسها & نوع بزوهش \\
\hline
\end{tabular}

\section{ارزيابى كيفى ثيزوهشها}

هدف ارزيابى، دستيابى به خطاها و برجسته كردن ضعفهاى يروهشهاى ييشين نيست؛ بلكه

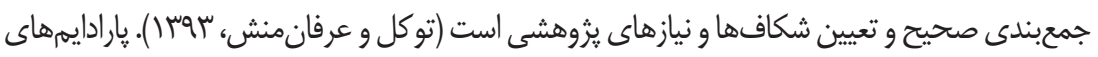
وإِ

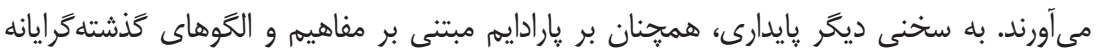

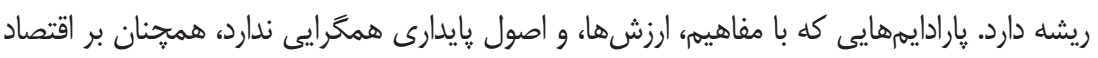
و رشد اقتصادى و الكوهاى رفتارى مصرفترايى و نايايدار مبتنى است (جاودانى و ميلىمنفرد، كوسا).

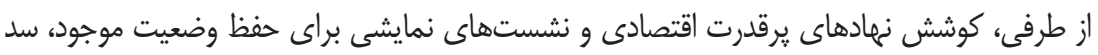

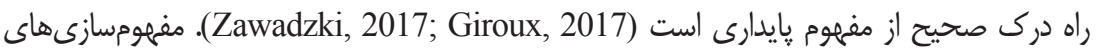

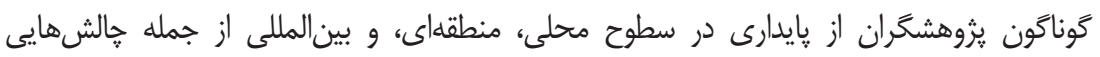

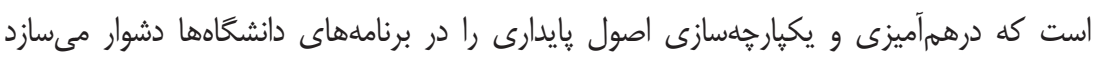


(Alexander, 2015). براى حل קنين دشوارىهايى، در آغاز كَفتكوى بيندانشخاهى ضرورى است. به نظر مىرسد كه ديخر نمىتوان بايدارى و دانشخاه يايدار را فقط بهسان كَفتمانى نظريهيردازازانه در كنار

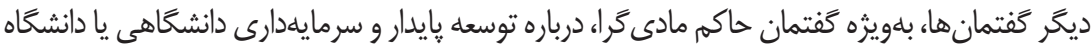

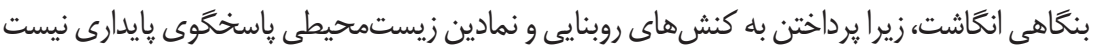

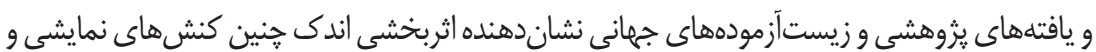
كوتهبينانه هستند (جاودانى و حمزهرباطى، لوست (ا). يرسش اصلى اين است كه آيا يارادايمهاى رايج مىتواند به تحقق دانشعاه بايدار، پايدارى محيطزيست، كيفيت زندگى، و رفع فقر كمى كند؟ براى ياسخ به اين يرسش، جدول (T) رويكرد سه

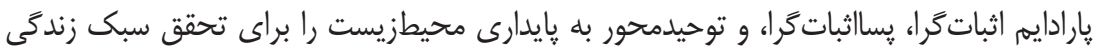

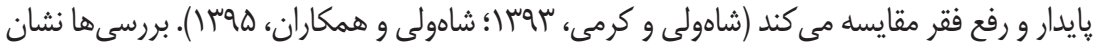

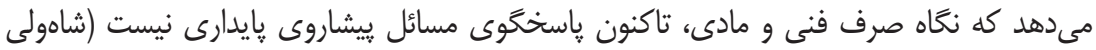
و همكاران، عNب()؛ زيرا معرفت علمى، كه محصول فرايند يزوهشهاى علمى است با خصيصه آزمونيذيرى واقعيات تجربى تعريف مىشود؛ كه در هر حال، ياسخگكىى يرسشهايى نيست كه به

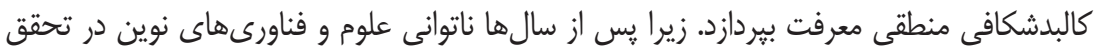

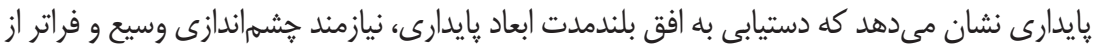

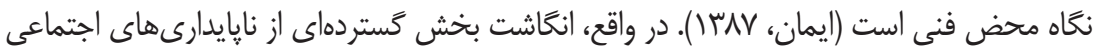
و زيستمحيطى ايران ناشى از ناكاركردى و بدكاركردى نهادهاى دانشكاهى و آموزش عالى و درى الته

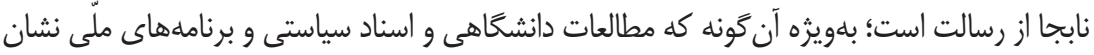

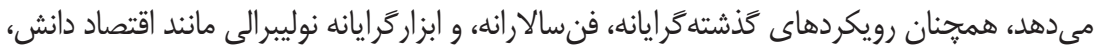

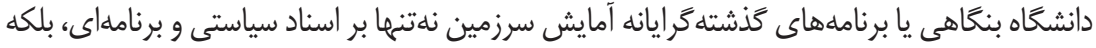

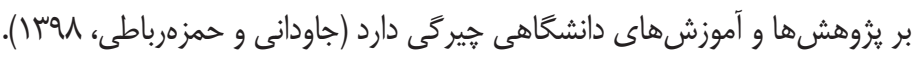
فراتركيب در يروهش حاضر مشخص مى كند كه غفلت از هستى شناسى و غايتشناسى المى مورد نياز يزوهش يايدارى در دانشكاهها (مطهرىنزاد و همكاران، أوجسا)، نشناختن مفهوم يايدارى از توسعه

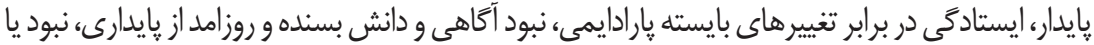

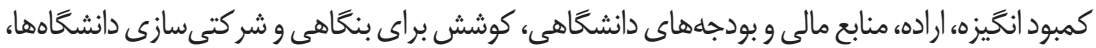
كالايىسازى دانش، و تجارىسازى يادَيرى و آموزش (Zawadzki, 2017; Giroux, 2017)، موانع عمده بإيدارى در آموزش عالى و تحقق دانشخاه پايدار هستند.از اينرو، نظام آموزش عالى بايدار با كذار

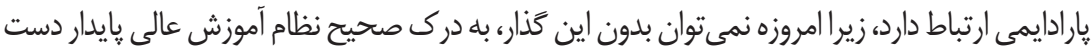


يافت. در ادامه اجزاى ينج گانه پارادايم توحيدمحور كه داراى جامعترين راهكارها براى دستيابى به پايدارى در

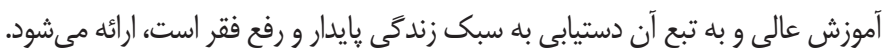

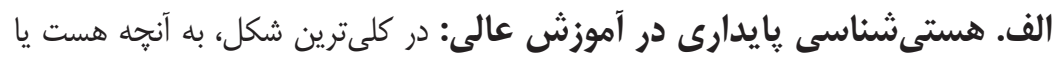

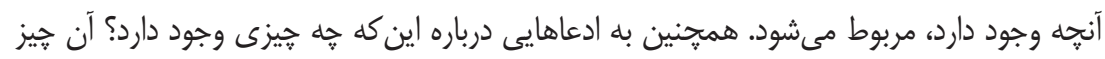

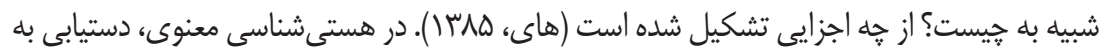

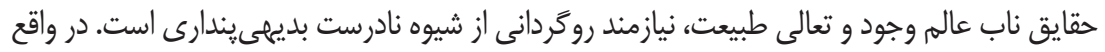

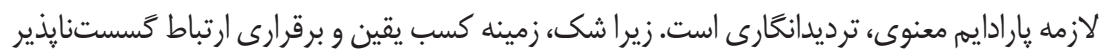
با خالق هستى است. اين نوع هستىشناسى، علاوه بر تجربه و مشاهده بيرون، بر تجربه شخصى و

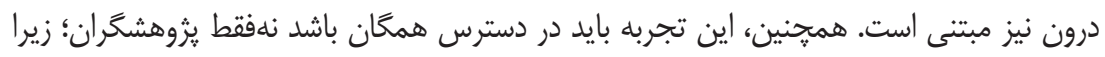

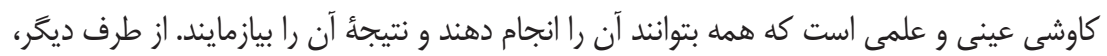

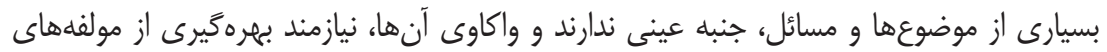

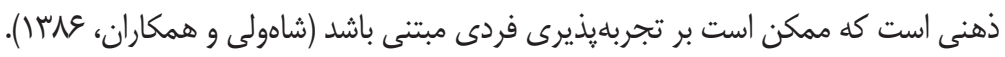

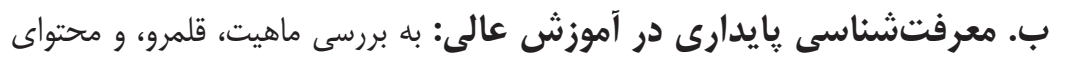

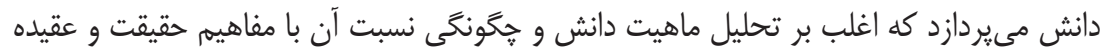

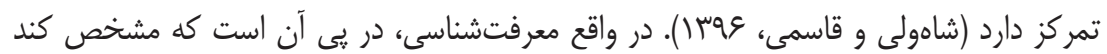

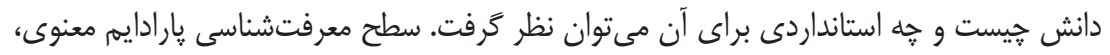

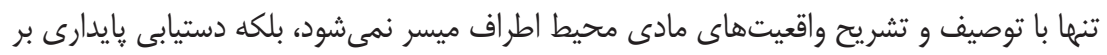

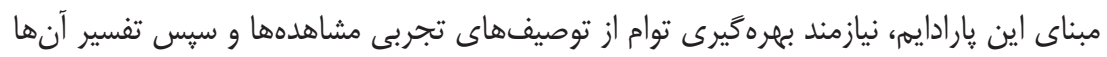

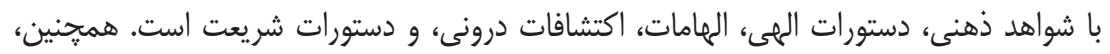

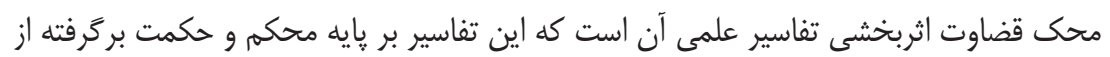
رحمت المى استوار باشد (شاهولى و همكاران، عرس آ).

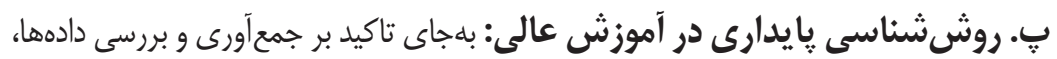

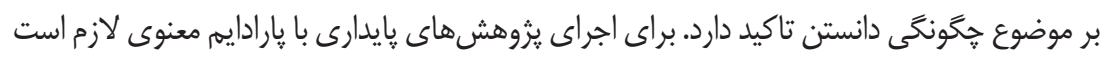

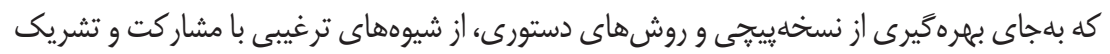

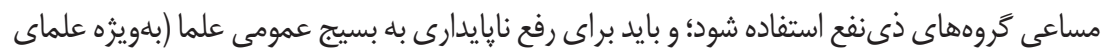

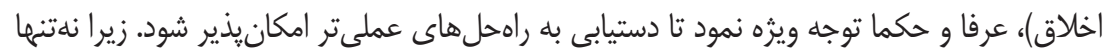

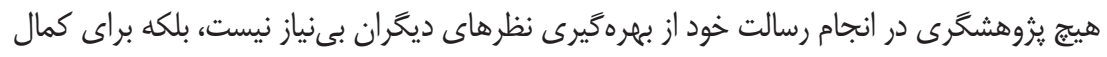

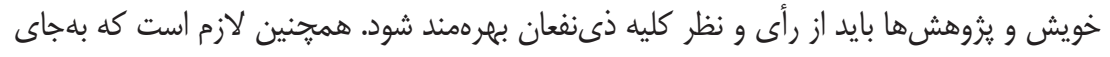


تكيه بر روشهايى نظير محاسبه نتايج و ارزشيابى مبتنى بر قضاوتهاى سوكيرانه و يكجانبه به

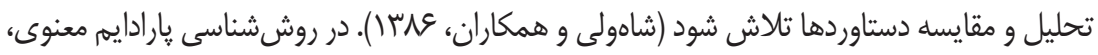

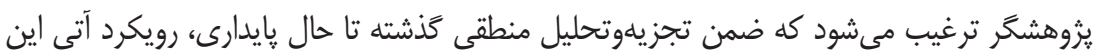
تغييرها را نيز با تفسيرى حكيمانه ترسيم كند (شاهولى و قاسمى، عوسبا ).

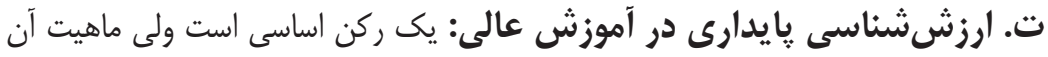
در پارادايم معنوى، با ديخر يارادايمها تفاوت دارد كه در ارزششناسى يارادايم معنوى، يُانه غايت

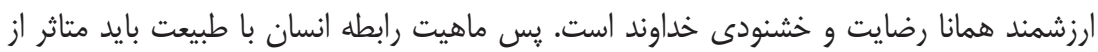

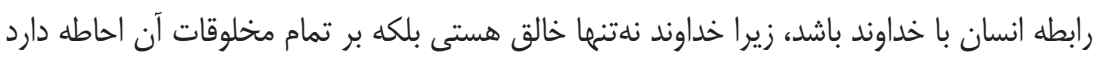

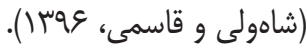

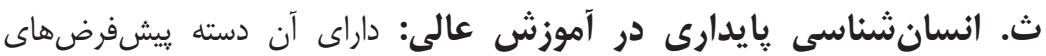

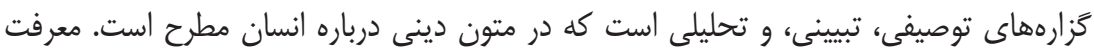

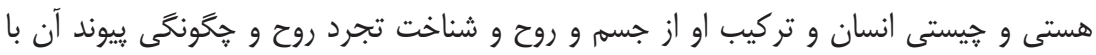

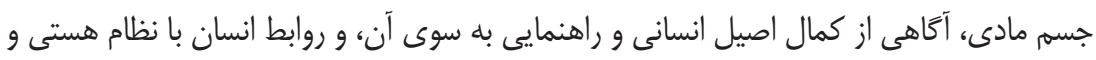

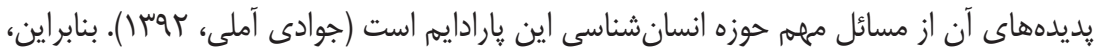

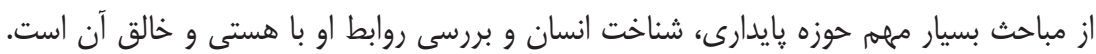

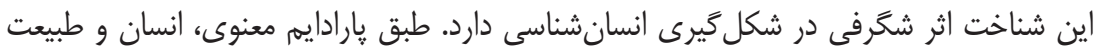

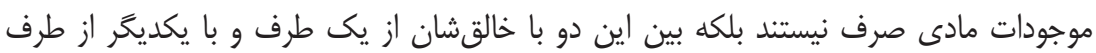

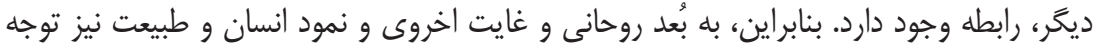

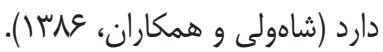

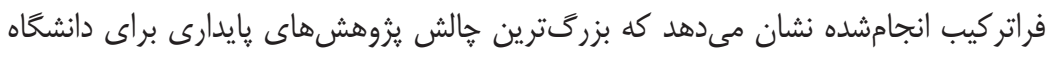

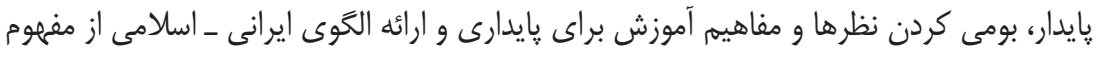

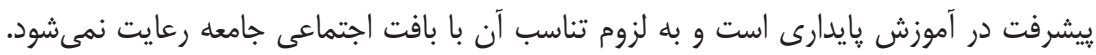

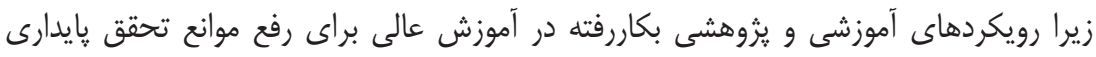

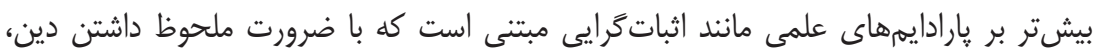

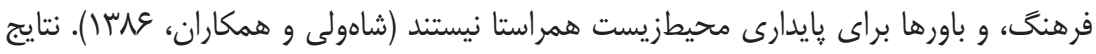
نشان مىدهد كه اين يزوهشها در تشريح مفهوم و سير تاريخى موضوعهاى بايدارى متوقف

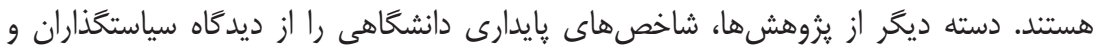

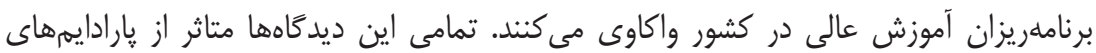




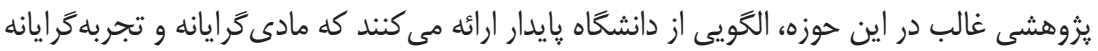

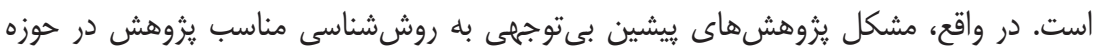

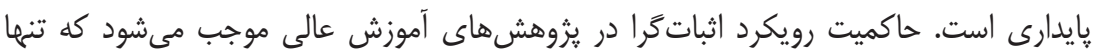

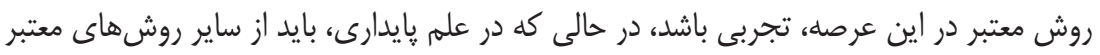

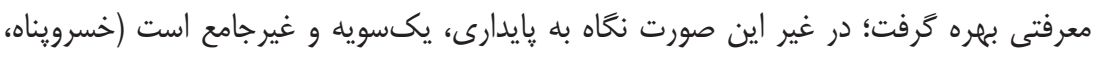

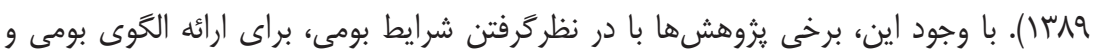

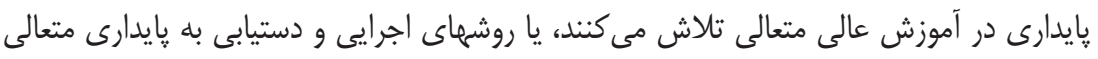

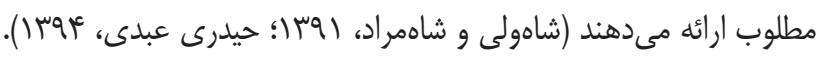

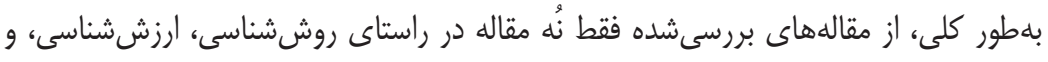

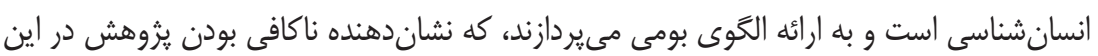

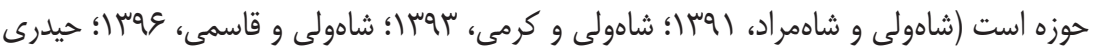

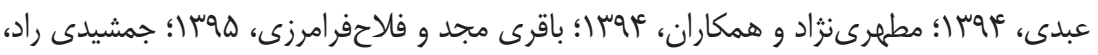

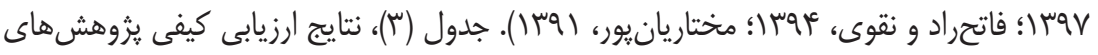

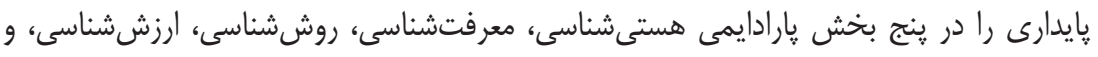
انسانشناسى نشان مى دهد.

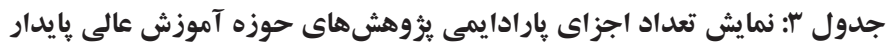

\begin{tabular}{|c|c|c|c|c|c|}
\hline انسانشناسى & ارزششناسى & روشخونگى / روشى & معرفتشناسى & هستى شنساسى / & لمها \\
\hline r & r & 0 & ro & IT & فراوانى \\
\hline
\end{tabular}

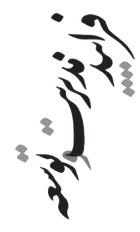

الحَوهاى بهدستآمده از TV منبع مورد مطالعه، تركيبى از الخوهاى يديدارشناسانه و اثبات كَر ايانه است كه به دليل محدوديت در هستىشناسى، معرفتشناسى، و روششناسى، باعث اضمحالال

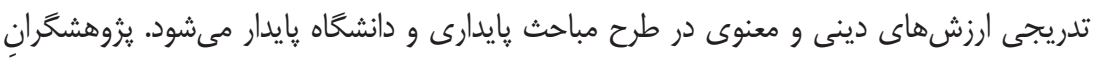

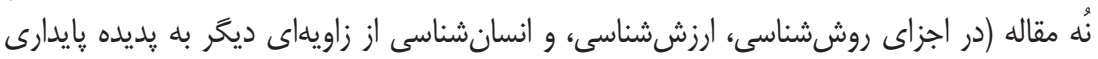

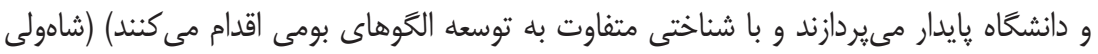

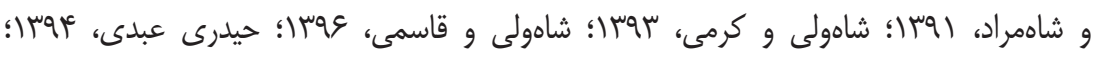

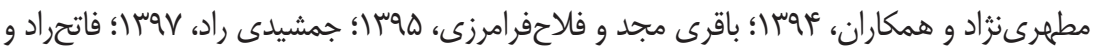




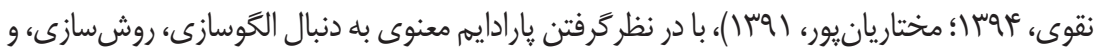

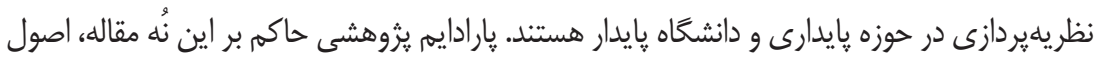
روششناسى بارادايمهاى اثباتكرا، تفسيرى، و انتقادى را نفى نمى كند، ولى با تمام توانمندىهاى

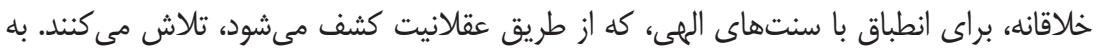

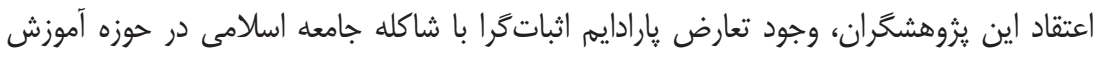

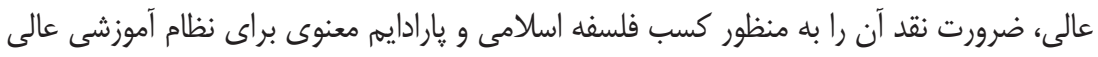

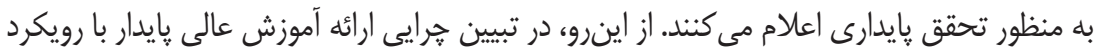

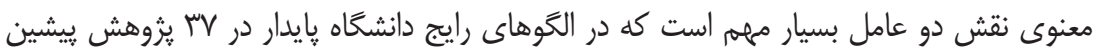

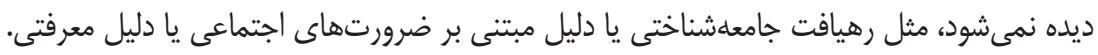

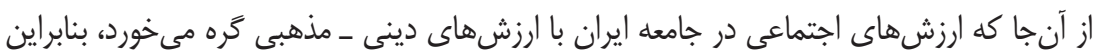

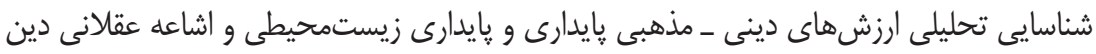

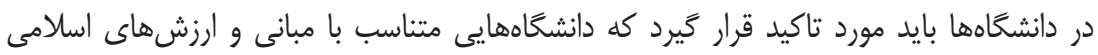

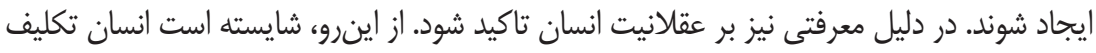

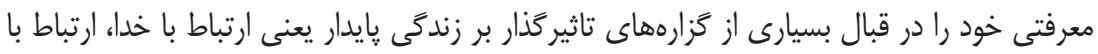

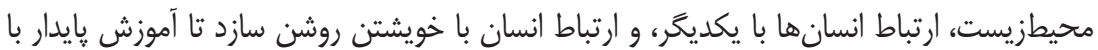

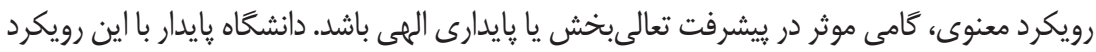

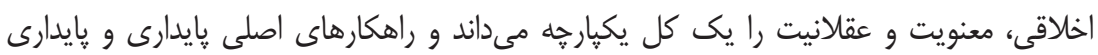

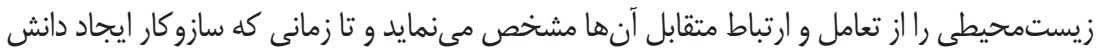

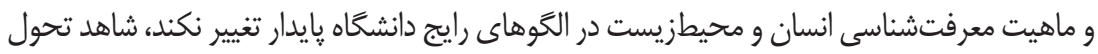

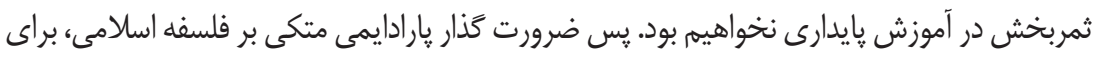

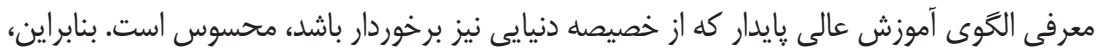

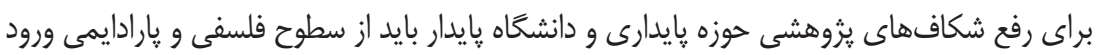

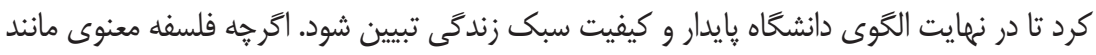
فلسفه اسلامى به هستىشناسى و معرفتشناسى محيطزيست توجه مى كند، ولى فقدان فعاليتهاى تئين سازمانيافته و منظهم كه اين فلسفه را به سطح يارادايم و سيس نظريه و الكَ وارد نمايد، از ابهامهاى

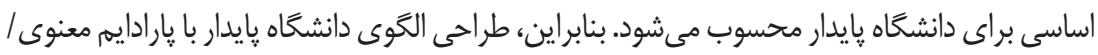

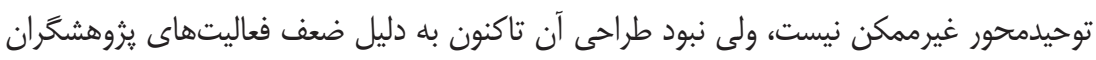
معتقد به فلسفه المهى مربوط است، نه ماهيت و ذات اين فلسفه. 


\section{يافته ها}

يافتهها در دو بخش ارزيابى منابع و تحليل نتايج آن تشريح مىشود.

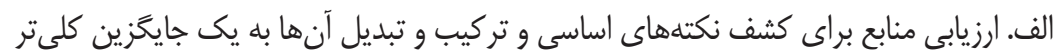

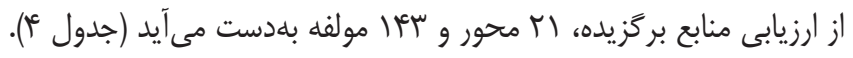

\section{جدول ^ا: ارزيابى منابع مورد مطالعه بير امون عوامل موثر بر هايدارى آموزش عالى در جشمانداز توسعه يايدار كشور}

\begin{tabular}{|c|c|c|}
\hline مولفهها & كد محورى & رديف \\
\hline 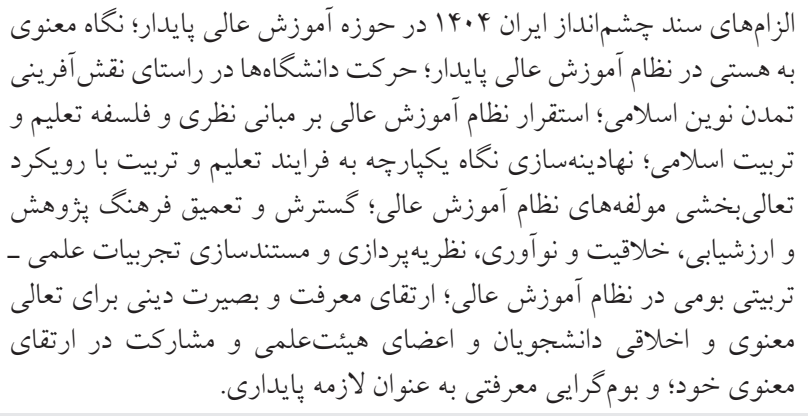 & فرهنگ پِايدارى & 1 \\
\hline 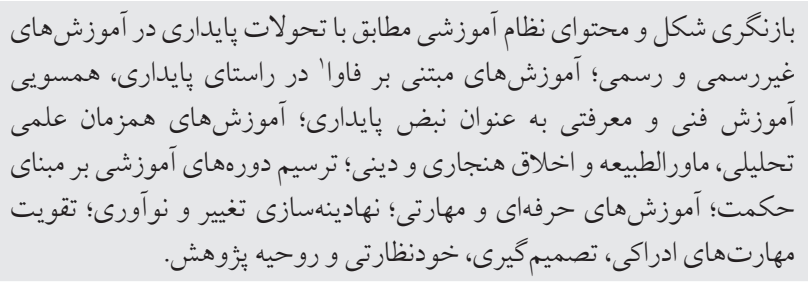 & آموزش بِايدارى & r \\
\hline 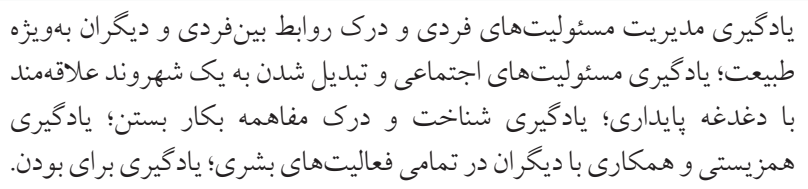 & يادگيرى پايدارى & r \\
\hline 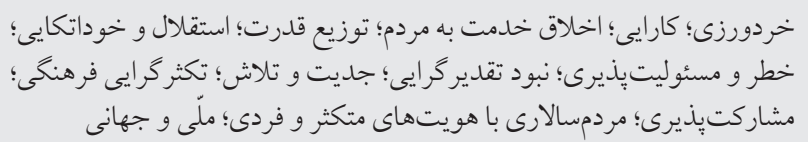 & تِ يايدارى & r \\
\hline
\end{tabular}


ادامه جدول †: ارزيابى منابع مورد مطالعه ييرامون عوامل موثر بر پايدارى آموزش عالى در جشمانداز توسعه پֶايدار كشور

رديف كد محورى مولفهها

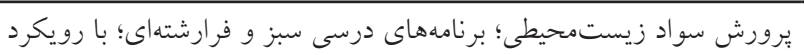

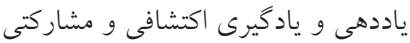

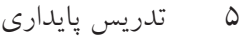

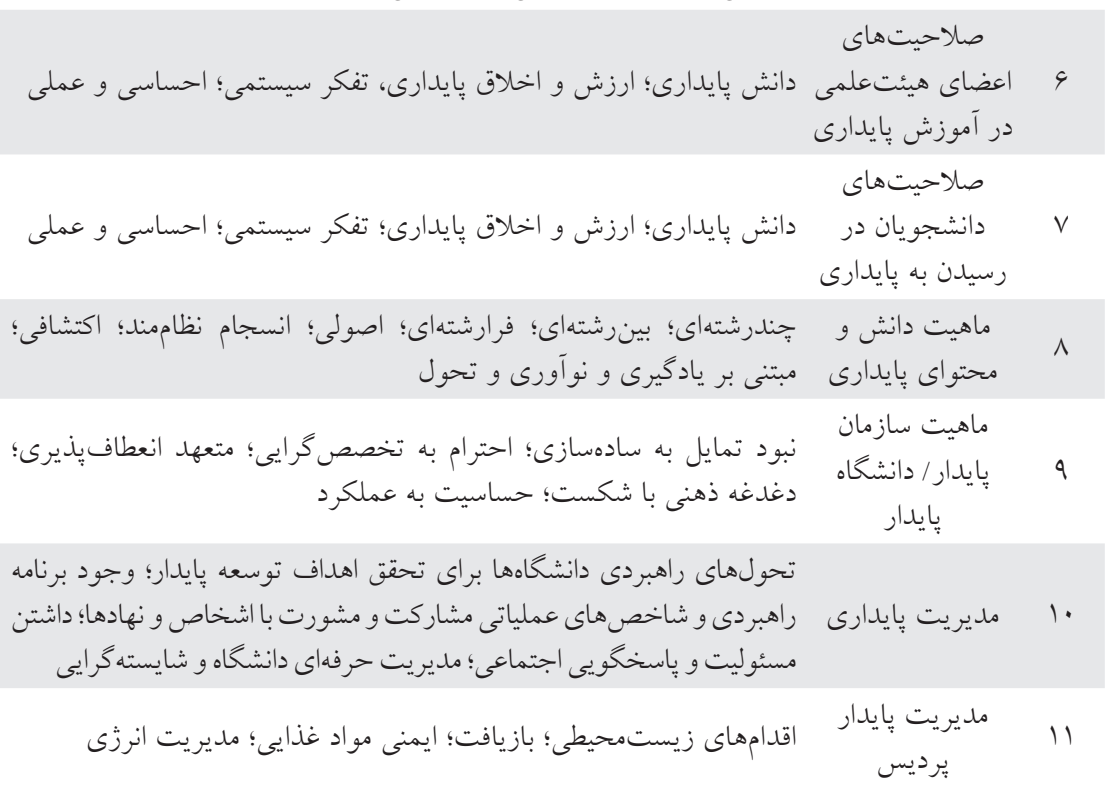

فراتر رفتن از استنباط مبتنى بر مشاهده و الكوهاى برآمده از مشاهدهها؛ نغاه

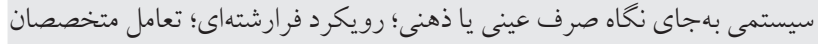

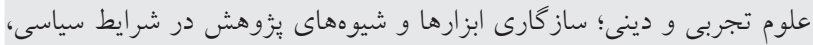

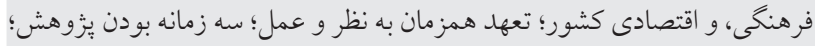

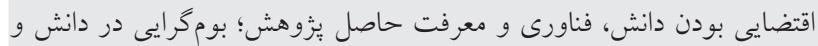

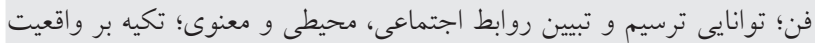

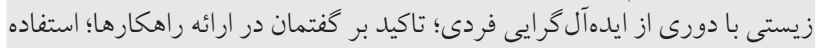

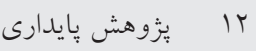

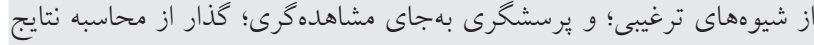

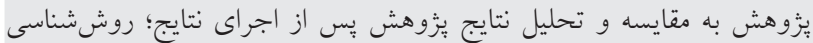

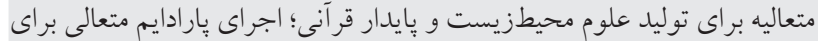

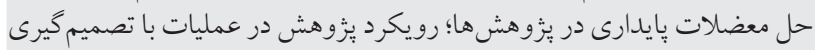

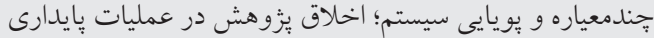


ادامه جدول †٪: ارزيابى منابع مورد مطالعه ييرامون عوامل موثر بر هايدارى آموزش عالى در

جشمانداز توسعه هِايدار كشور

رديف

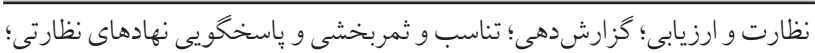

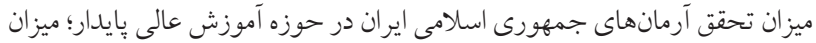

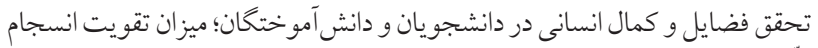

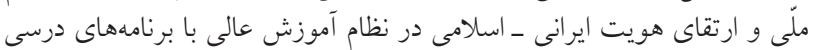
إنظارت

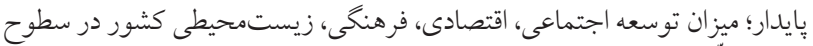

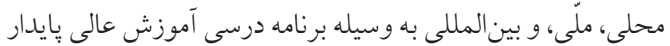

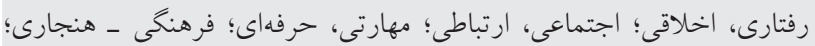

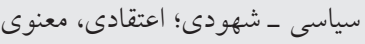

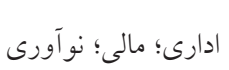

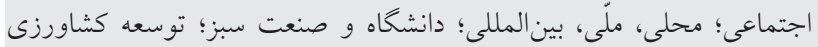

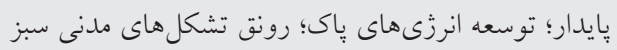
ادارى و مالى بايدارى

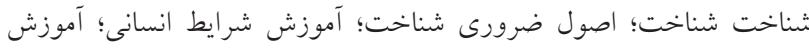
هويت زمينى؛ رويارويى با ترديدها

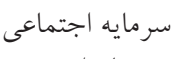

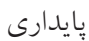

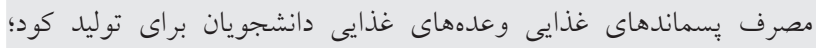

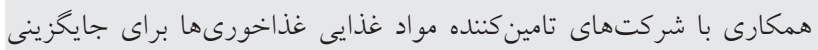

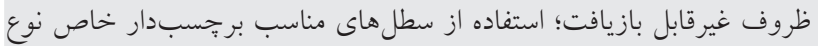

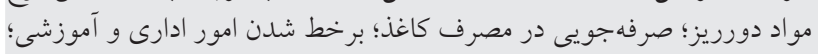

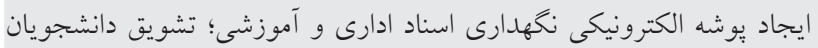
زيرساختهاى يايدارى 11

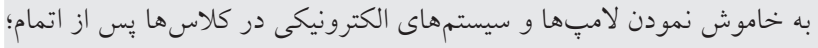

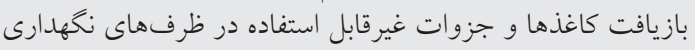

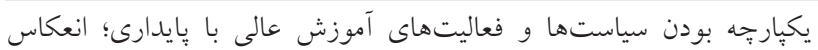

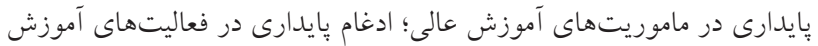

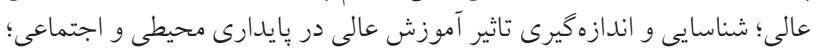

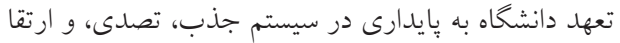
19

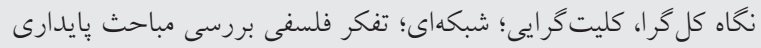

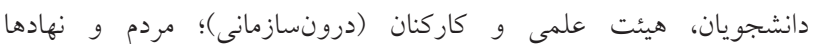
(برونسازمانى) (بئن)

از عثا منبع داخلى یايدارى در آموزش عالى، تعداد كدهاى محورى به تفكيك (فراوانى و درصد

$$
\text { فراوانى) استخراج مىشود (جدول ه). }
$$


جدول ه: توزيع فراوانى كدهاى محورى منابع

\begin{tabular}{|c|c|c|}
\hline درصد & تعداد & كدها \\
\hline $0 / 09$ & $\wedge$ & فرهنگ \\
\hline $11 / 1 \wedge$ & 19 & 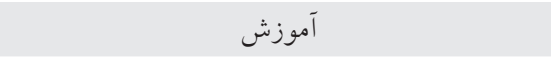 \\
\hline $4 / 19$ & 4 & 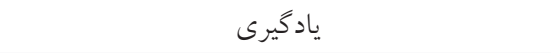 \\
\hline $9 / 79$ & 9 & 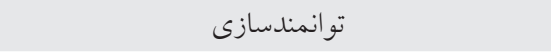 \\
\hline r/Vq & $r$ & 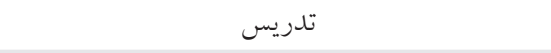 \\
\hline$r / \uparrow q$ & Q & 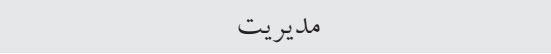 \\
\hline$r / 4 q$ & Q & صلاحيتهاى اعضاى هيئتعلمى \\
\hline$r / 4 q$ & Q & صلاحيت هاى دانشجويان \\
\hline $0 / 09$ & $\wedge$ & ماهيت دانش و محتو اى پايدارى \\
\hline$r / 4 q$ & Q & ماهيت سازمان بِيدارى (دانشخاه بِايدار) \\
\hline r/Vq & r & مديريت پِايدار يرديس \\
\hline $1 \% / 91$ & r. & 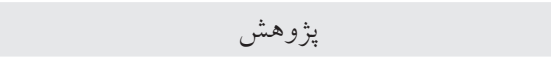 \\
\hline $4 / \wedge 9$ & $\vee$ & 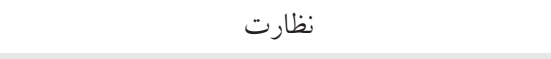 \\
\hline $4 / 19$ & 4 & 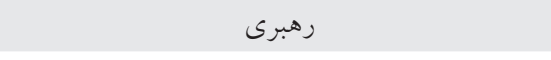 \\
\hline$r / \cdot 9$ & $r$ & 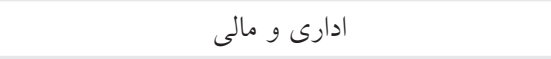 \\
\hline Q/DQ & $\wedge$ & 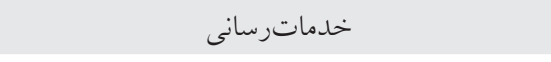 \\
\hline $4 / 19$ & 4 & دانش مبتنى بر سرمايه اجتماعى براى تحقق پِيدارى \\
\hline $0 / 09$ & $\wedge$ & زيرساخت هاى هِيدارى \\
\hline$r / 4 q$ & $\Delta$ & 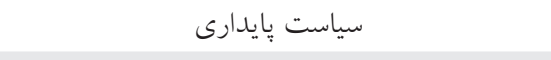 \\
\hline$r / \cdot 9$ & $r$ & 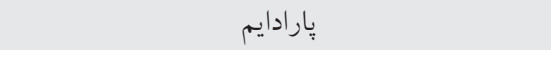 \\
\hline $1 / 4$ & r & 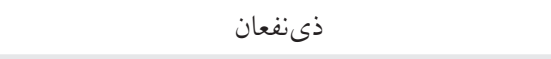 \\
\hline $1 \cdots$ & Ifr & 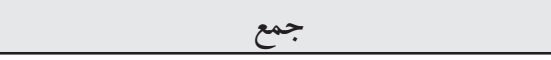 \\
\hline
\end{tabular}

ب. تحليل ارزيابى تفاوت درك بنيادى يار ادايمهاى رايج يايدارى و توحيدمحور و

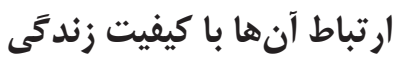

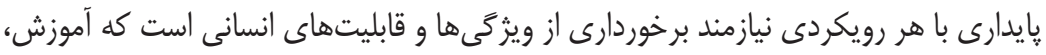

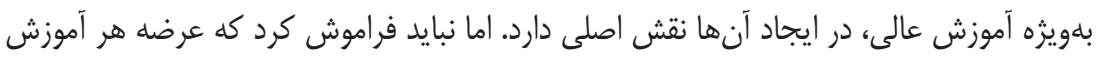

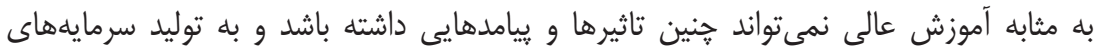


اجتماعى بينجامد، ولى فهرست هنجارها و ارزشهايى كه آموزش عالى براى تحقق بايدارى بايد

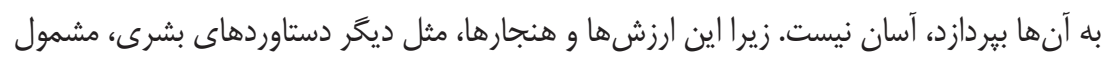

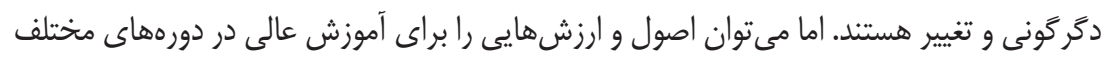

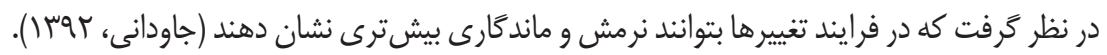

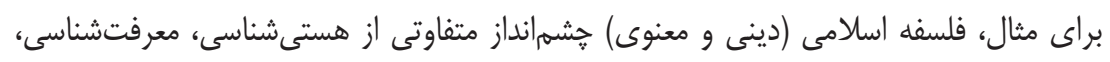

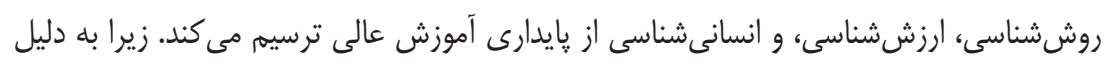

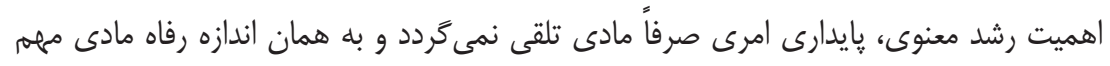

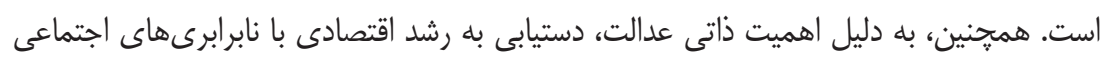

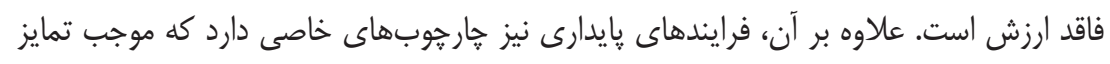

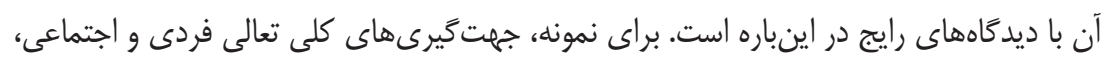

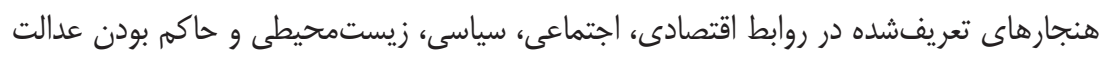

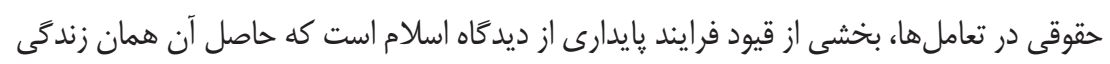

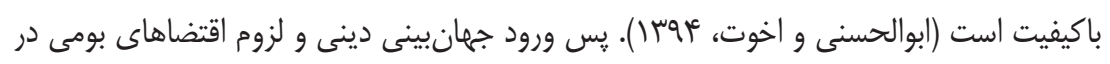

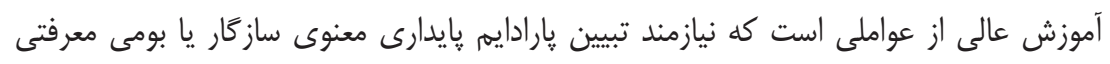

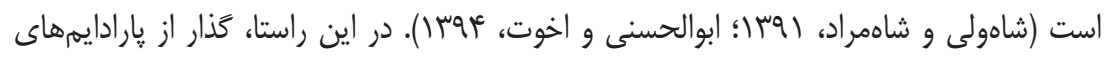

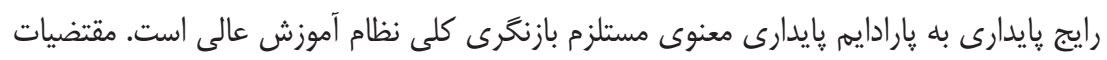

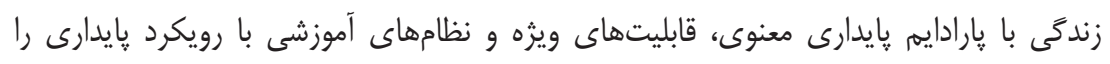

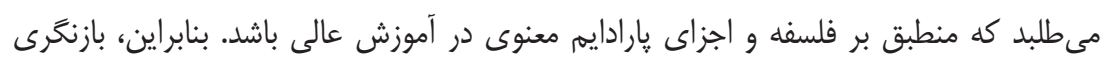

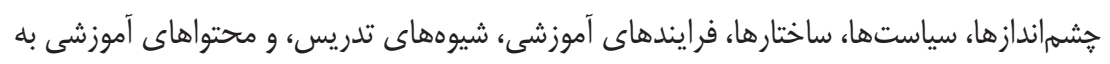

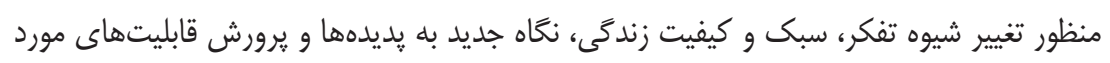

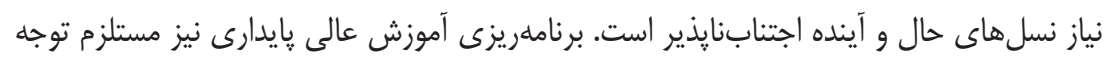

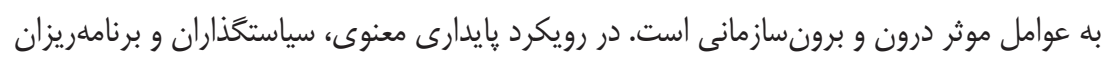

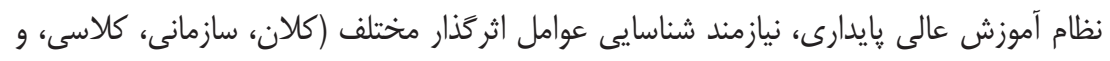

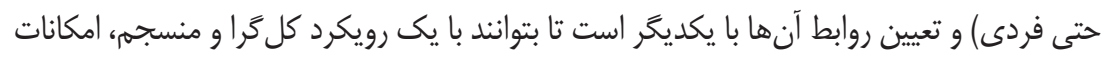

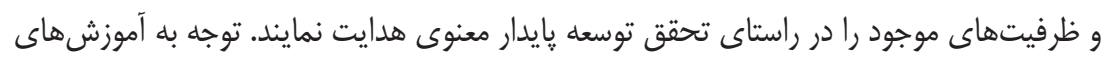

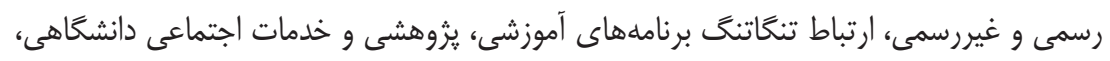

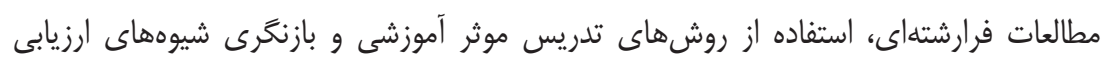

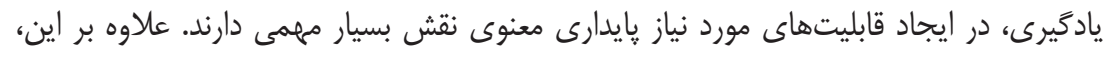


دانشكاههاى سبز مبتنى بر دين و معنويت مىتواند نقشه راه و الحَوى عملى سازمان ها و نهادها در مدير يت نرمافزارى و سختافزارى توسعه پايدار مبتنى بر بوم فنى و معرفتى كشور محسوب شوند

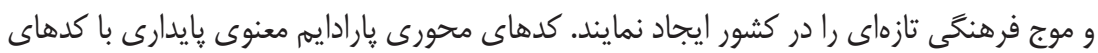
مشابه در پارادايمهاى رايج پايدارى در جدول (و) مقايسه مى مشوند.

\section{جدول צ: مقايسه پارادايمهاى پايدارى رايج و معنوى در آموزش عالى}

\begin{tabular}{|c|c|c|c|}
\hline بارادايم معنوى بِايدارى & هارادايم رايج هايدارى & كد محورى & رديف \\
\hline 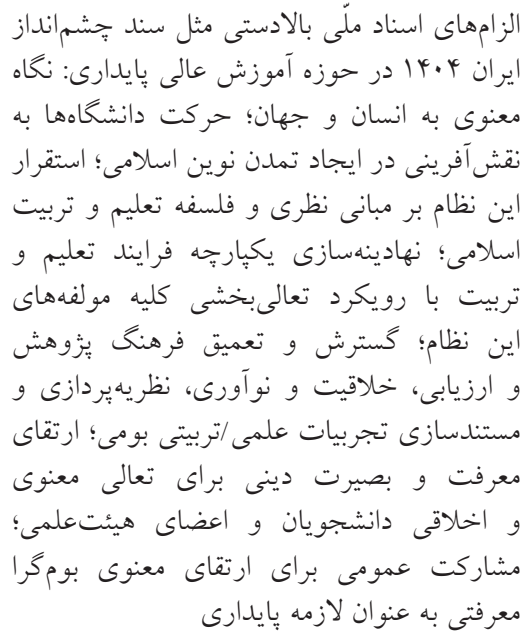 & 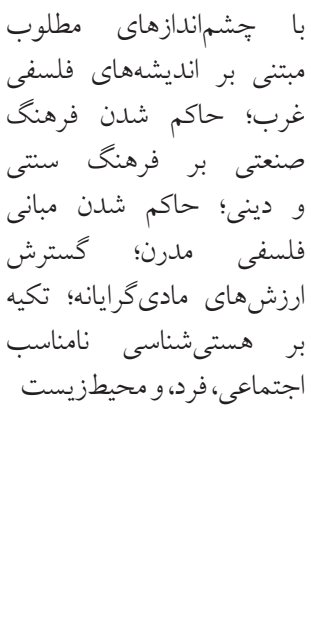 & نظام فرهنَح & \\
\hline
\end{tabular}

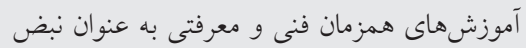

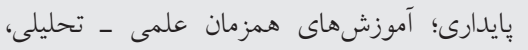

r ب آنظام آموزشى بازنخرى شكل و محتواى نظام

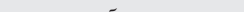

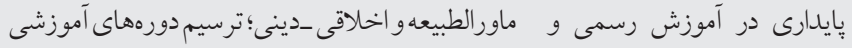

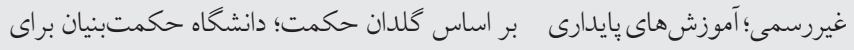

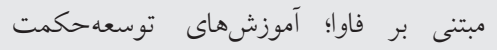

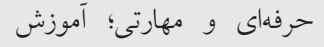
نهادينه شدن تغيير و نوآورى؛ تهون

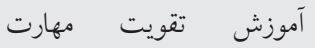
ادراكى؛ آموزش ت تصويت تهويت مهارت تصميم گيرى؛ آموزش تصن خودنظارتى؛ آموزش رويري؛ آمرزشيه

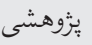


ادامه جدول \&: مقايسه پارادايمهاى پايدارى رايج و معنوى در آموزش عالى

\begin{tabular}{|c|c|c|c|}
\hline پارادايم معنوى پِايدارى & پارادايم رايج يايدارى & كد محورى & رديف \\
\hline 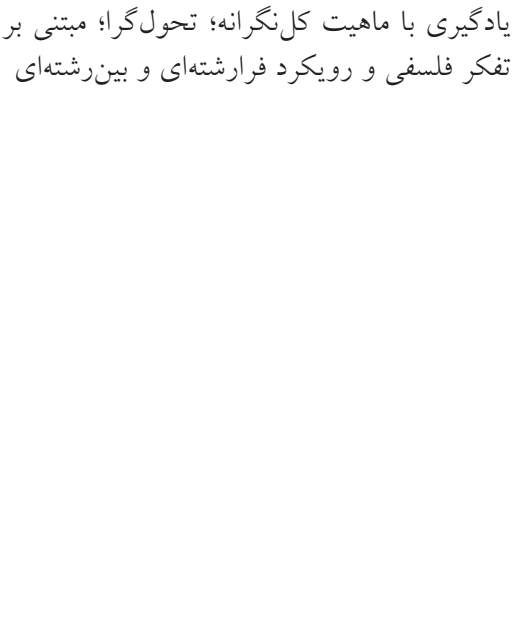 & 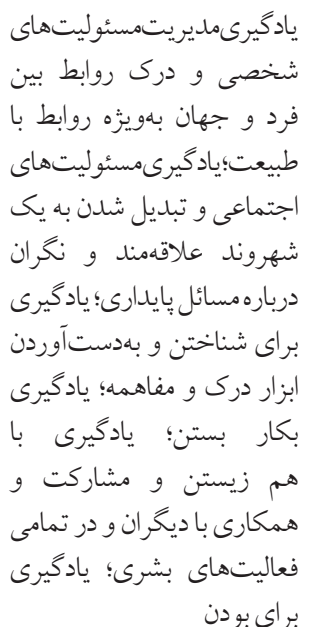 & نظام يادگيرى & $r$ \\
\hline خردورزى؛ اخلاق در خدمت مردم & 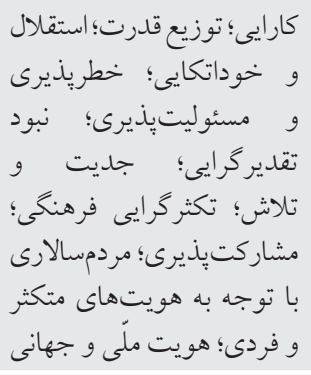 & 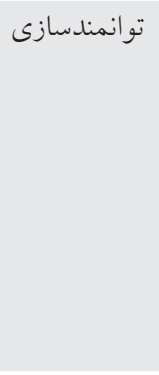 & $\varphi$ \\
\hline برنامه درسى فرارشتهاى & بروبامه درسى سو ادزيز؛ استفاده از بحيطى؛ & 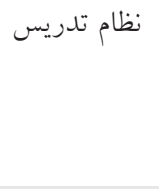 & 0 \\
\hline صلاحيت ارزشى و اخلاق بايدارى & 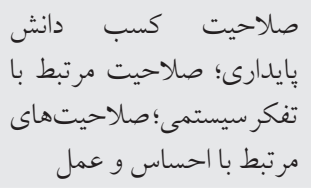 & صلاحيت هاى & 4 \\
\hline صلاحيت ارزشى و اخلاق بايدارى & 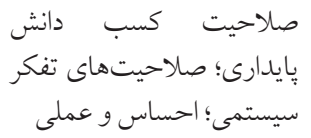 & صلاحيت هاى & V \\
\hline
\end{tabular}


ادامه جدول צ: مقايسه يارادايمهاى يايدارى رايج و معنوى در آموزش عالى

\begin{tabular}{|c|c|c|c|}
\hline يارادايم معنوى بِايدارى & پارادايم رايج يايدارى & 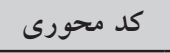 & رديف \\
\hline 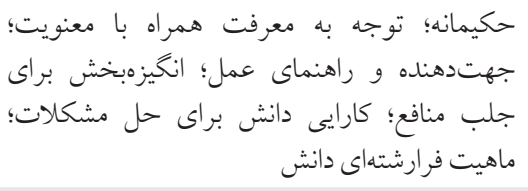 & اصنّا & محتو ماهيت دانش و & $\wedge$ \\
\hline & كارآفرين & ماهيت دانش & \\
\hline 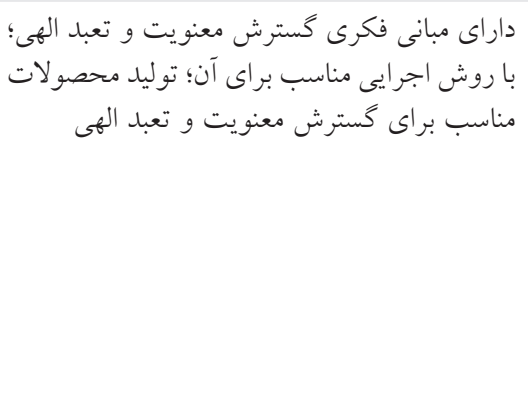 & 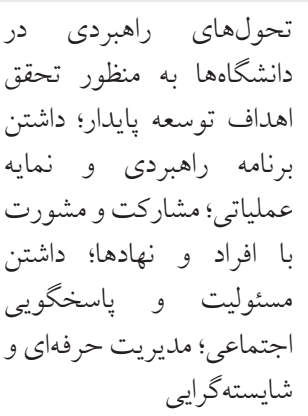 & 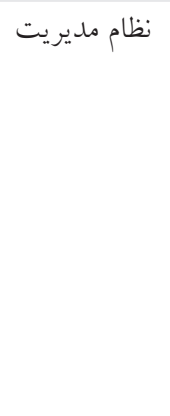 & \\
\hline 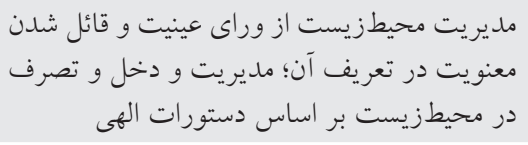 & 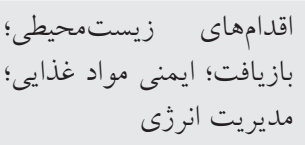 & زئز زيرديس مديريتى & 11 \\
\hline 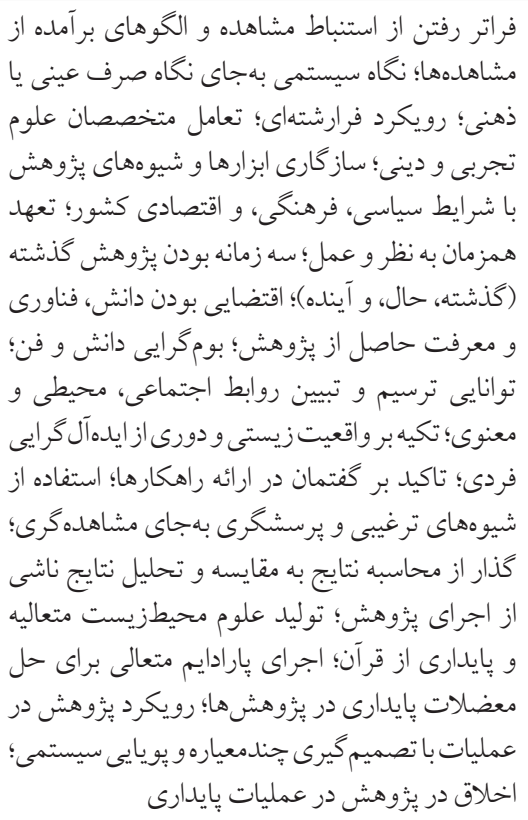 & 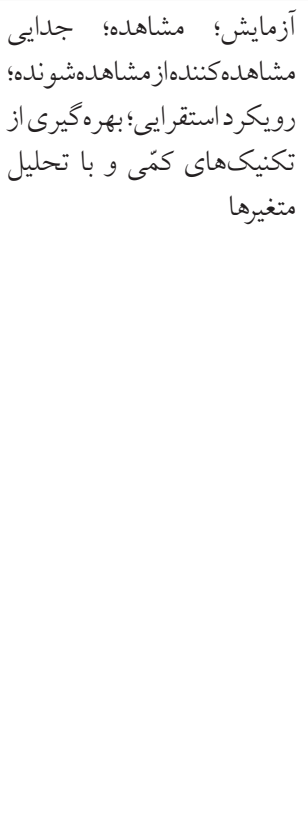 & نظام يزوهش & IT \\
\hline
\end{tabular}


ادامه جدول و: مقايسه يار ادايمهاى يايدارى رايج و معنوى در آموزش عالى

\begin{tabular}{|c|c|c|c|}
\hline يارادايم معنوى پِايدارى & پارادايم رايج هايدارى & كد محورى & رديف \\
\hline 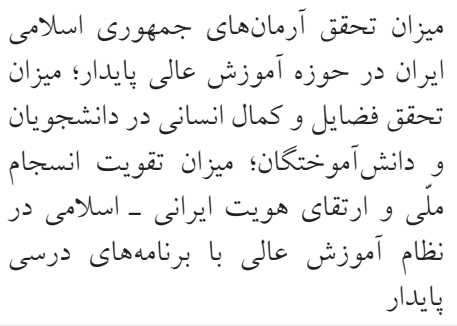 & 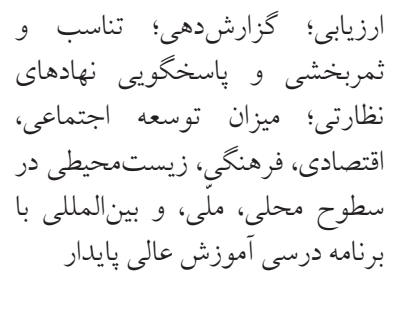 & نظام نظارت & $1 \pi$ \\
\hline 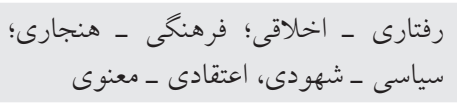 & اجتماعى - ارتباطى؛ مهارتى - & نظام رهبرى & 14 \\
\hline 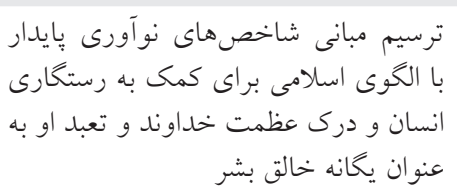 & ادارى؛ مالى؛ نوآورى & نظام ادارى و & 10 \\
\hline تستر معنويت براي ايجاد محيطزيست مناسب در & 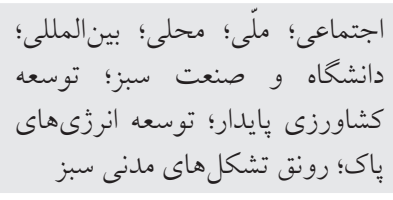 & 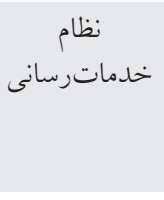 & 19 \\
\hline 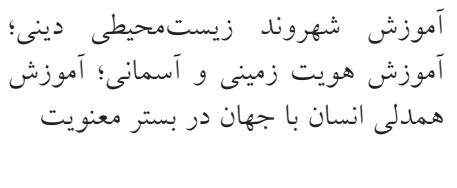 & 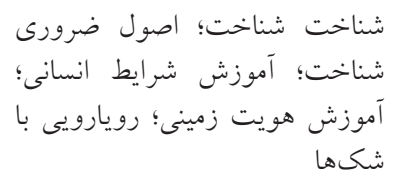 & ن اجتمام سرمايه & IV \\
\hline 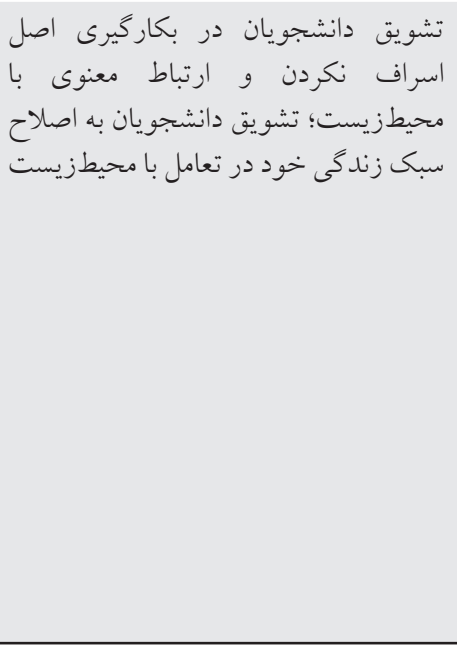 & 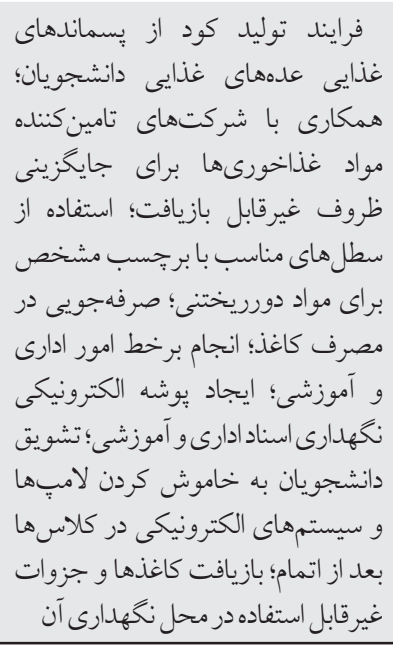 & زيرساختها & 11 \\
\hline
\end{tabular}


ادامه جدول ؟: مقايسه يارادايمهاى پايدارى رايج و معنوى در آموزش عالى

\begin{tabular}{|c|c|c|c|}
\hline پِارادايم معنوى پِايدارى & بارادايم رايج بايدارى & كد محورى & رديف \\
\hline 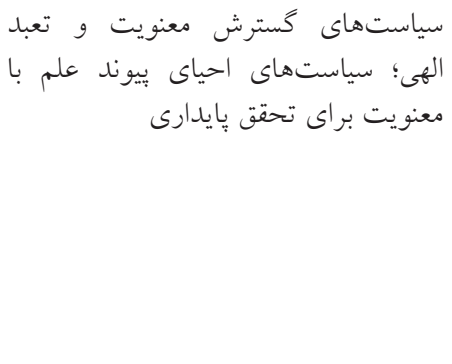 & 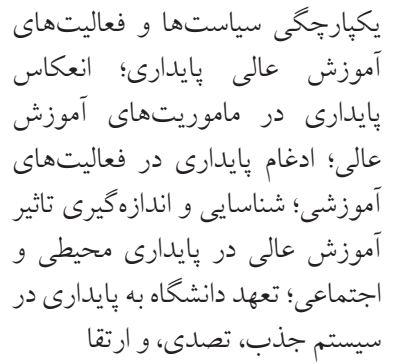 & نظام سياسى & 19 \\
\hline بررسى مباحث پِايدارى كليتگرا؛ تفكر فلسفى در & شبكانينى مادى؛ نگاه سيستمى - & عامل بار بادايم & r. \\
\hline 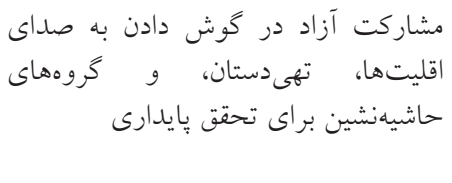 & 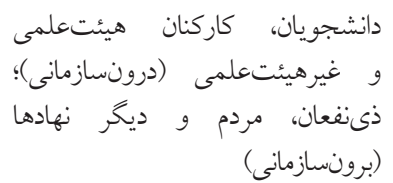 & ذى نفعان & rI \\
\hline
\end{tabular}

نتايج جدول (ع) نشان مىدهد، براى فهم و تبيين پايدارى بومانديش معنوى به يرداختهاى

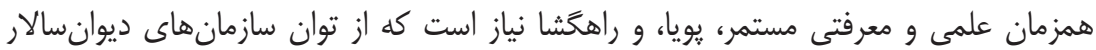
و شيوههاى اثبات گرايى دانشخاهى خارج است. در واقع، يايدارى نوعى افزايش ظرفيت مفاهمه

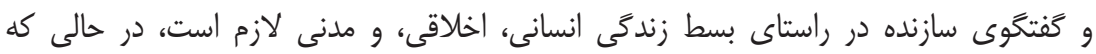
رفتار عجولانه و فنگرايانه حال حاضر، بر موانع تحقق קايدارى مىافزايد. براى مثال، رفتارهاى

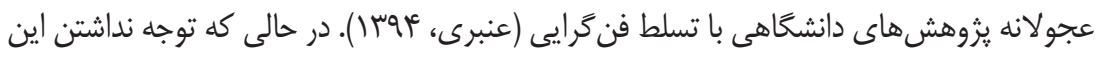
يزوهش ها به جنبههاى معنوى و شهودى، يا حذف آنها به دليل ضعف يارادايمى يزوهشَّران، بر هر فرايندى از جمله روششناسى يزوهش اثر كذارند. به همين دليل به يارادايم پايدارى نوين نياز است كه در حكمت، خرد، دانش عينى، و دانش بومَّرا ريشه دارند. با وجود اين كه هدف يايدارى، ارتقاى كيفيت زندگى است تا انسان از خود احساس رضايت كند، ولى با پارادايمهاى رايج پايدارى

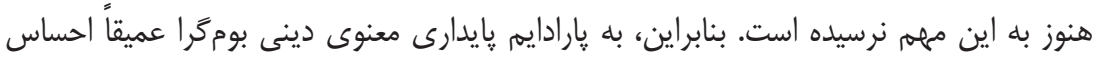

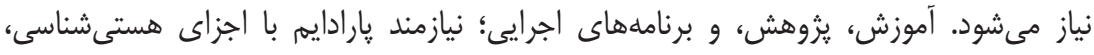
معرفتشناسى، روششناسى، ارزششناسى، و انسانشناسى دينى است كه از فراسوى طبيعت

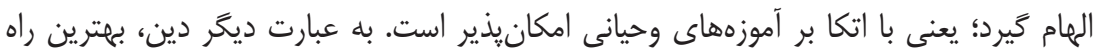


دسترسى به سبك زندگى با كيفيت بايدار را ارائه مىدهد و در بافت دينى بومگراست كه انسان

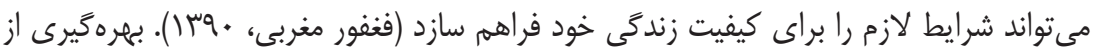

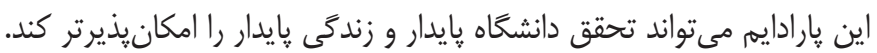

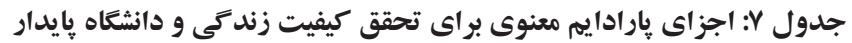

\begin{tabular}{|c|c|}
\hline مولفهها & \\
\hline 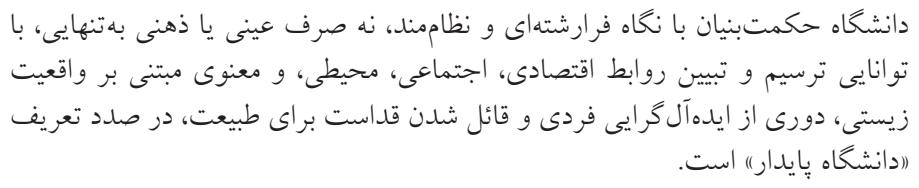 & \\
\hline 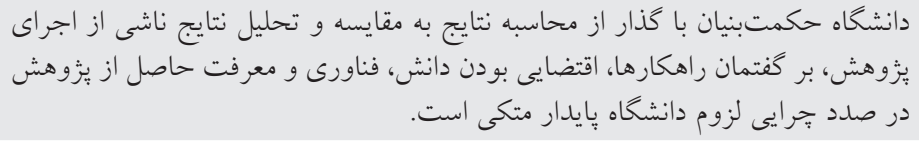 & \\
\hline 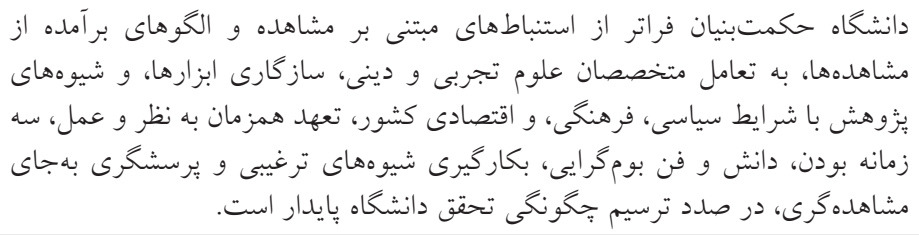 & روش: \\
\hline 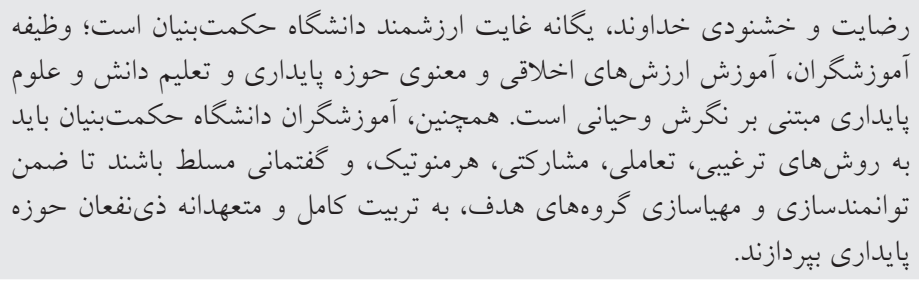 & \\
\hline 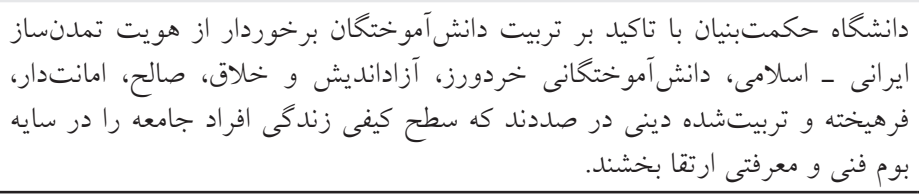 & \\
\hline
\end{tabular}

\section{بحث و نتيجه كيرى}

وجود ضعفها و محدوديتهاى يارادايمهاى رايج يايدارى باعث مىشود كه اين يارادايمها به دفعات

بازبينى و اصلاح شوند، ولى به دليل اشكالات بنيادى بينشها و فلسفى یايه، نمىتوانند انسانها را به رفاه آرمانى و كيفيت زندگى مورد نظر برسانند. يزوهش حاضر تلاش اوليهاى در گذار يارادايم است. 


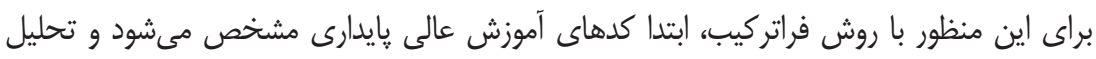

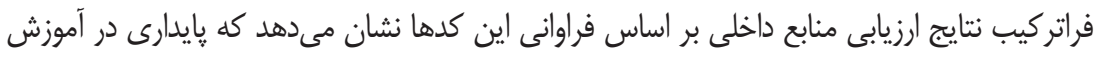

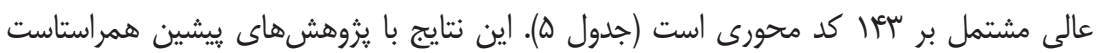
زال از (Lozano et al., 2013; Lozano et al., 2015; Calder \& Dautremont-Smith, 2009)

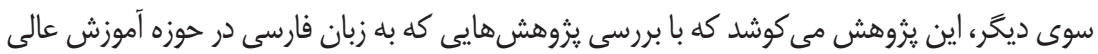

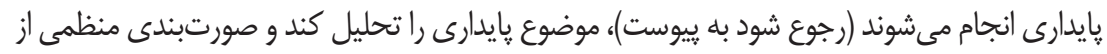

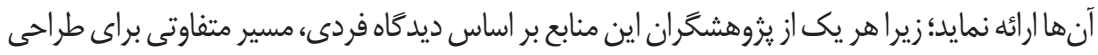

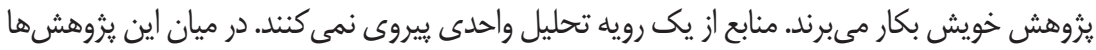

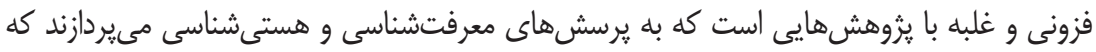

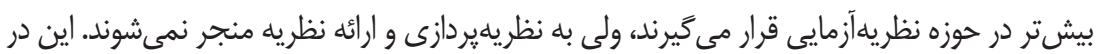

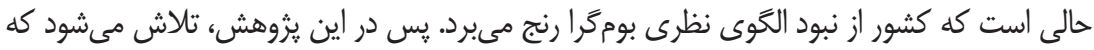

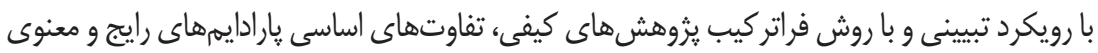

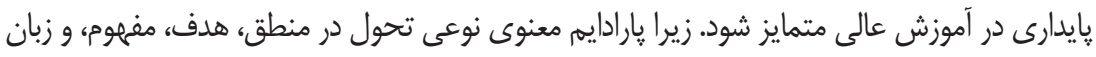

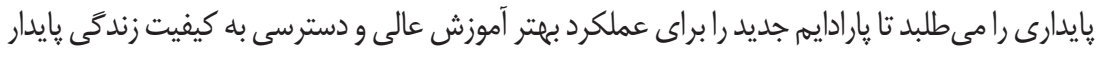

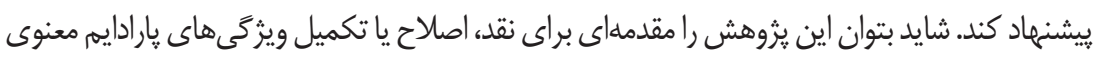

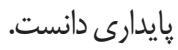

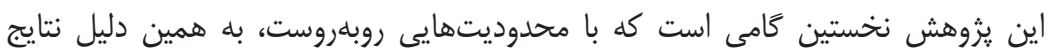

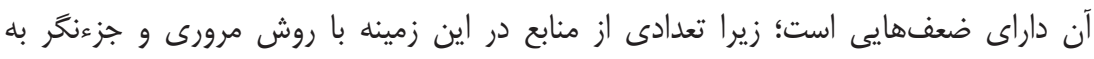

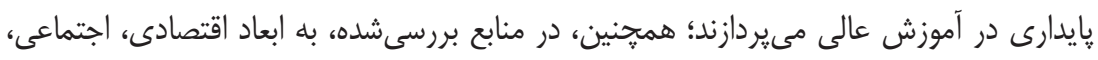

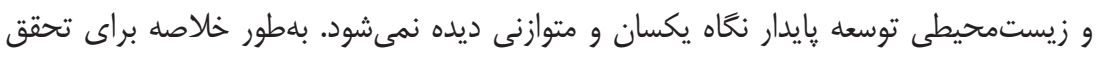

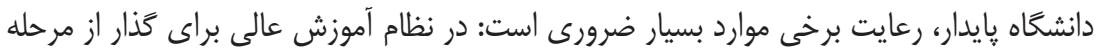

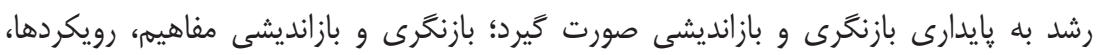

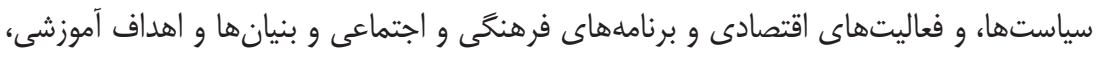

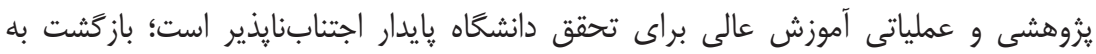

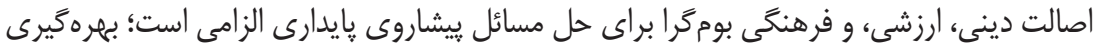

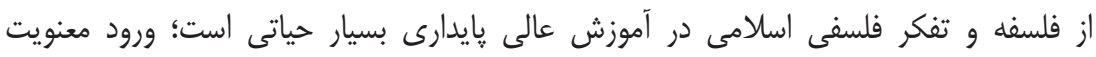

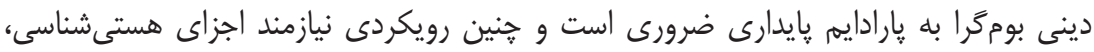

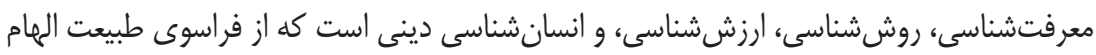


كَرفته باشد؛ يعنى به آموزههاى وحيانى متكى باشد؛ زيرا دين، بهترين راه تحقق كيفيت سبى

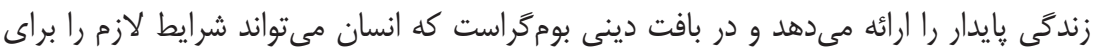
كيفيت محيط زندگى خود فراهم آورد. بنابر يافتهها، يُشنههادهاى كاربردى به دستاندر كاران نظام آموزش عالى كشور براى دانشعاه

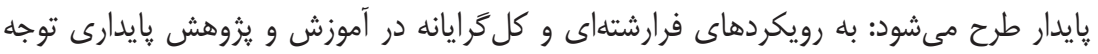
شود؛ از يروزههاى يُزوهشى توسعه پايدار متناسب با بوم فنى و معرفتى كشور حمايت گردد؛؛

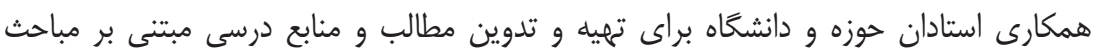
هايدارى معنوى مورد توجه واقع گردد.

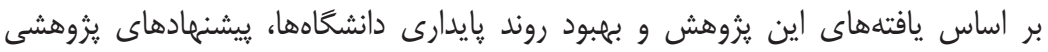

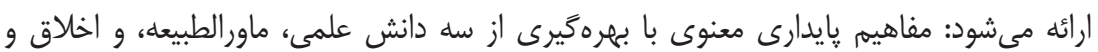
تبيين روابط آنها تبيين شود؛ الخويى براى ييادهسازى دانشگًاه يايدار مبتنى بر اسناد بالادستى در

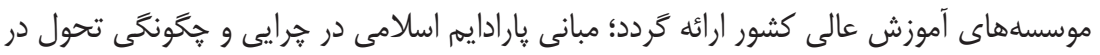
مولفههاى دانشگاه پايدار تبيين و تحليل شود؛ در روششناسى و محتواى مطرح در حوزه دانشگاه

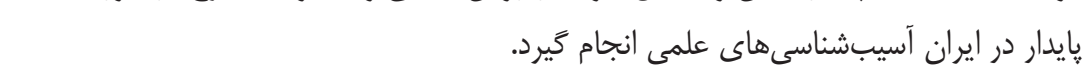

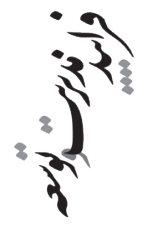

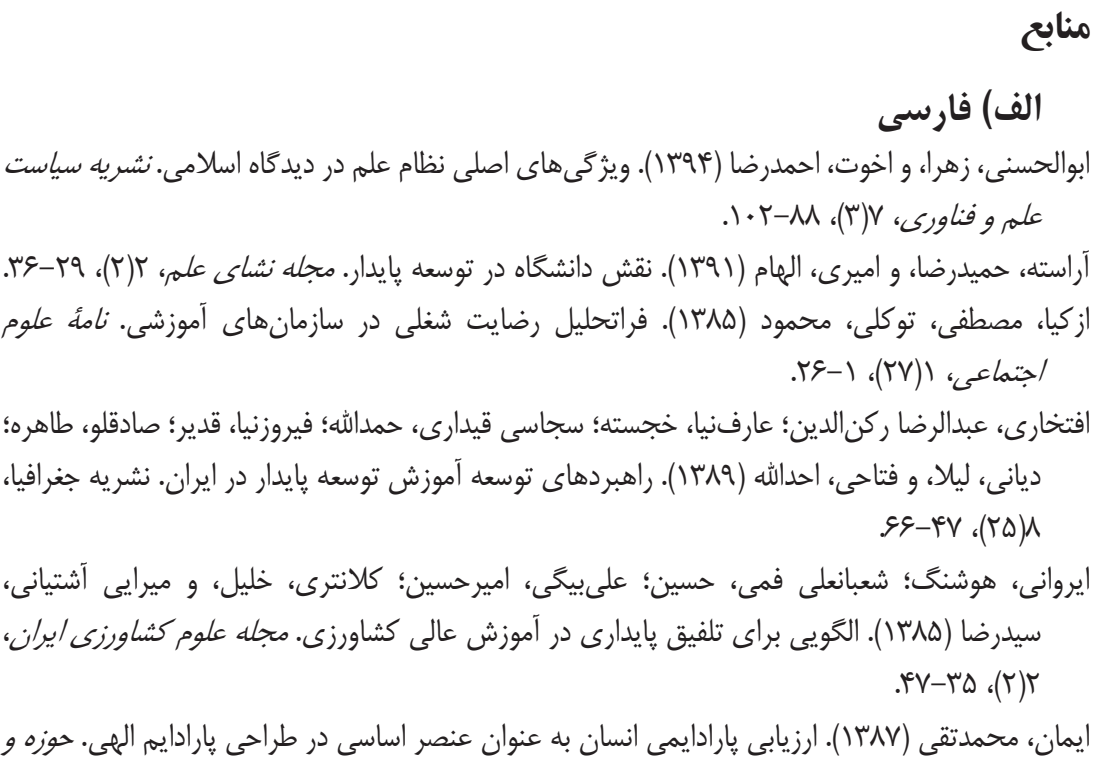




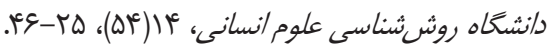

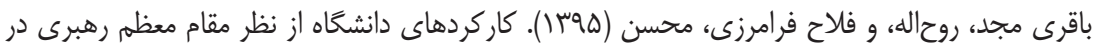

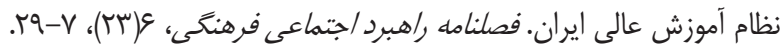

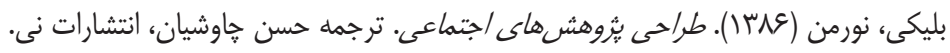

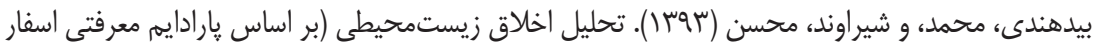

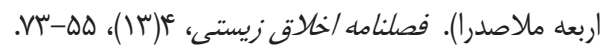

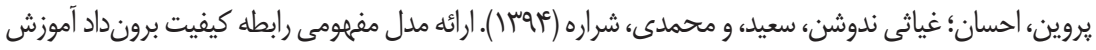

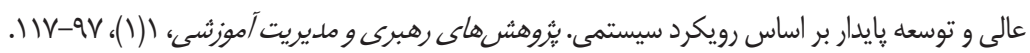

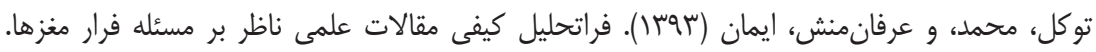

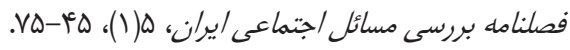

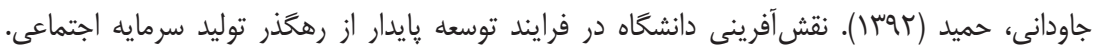

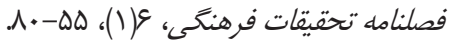

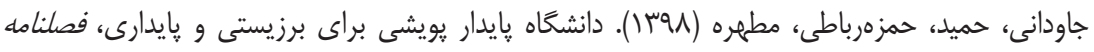

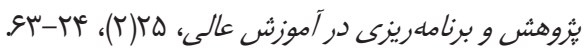

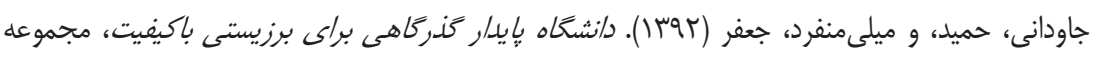
مقالات دومين همايش آموزش عالى و توسعه پايدار.

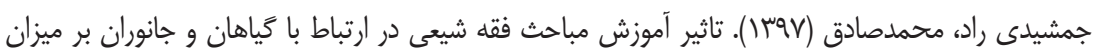

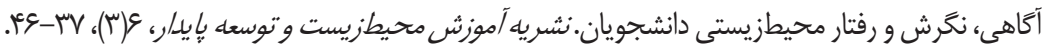

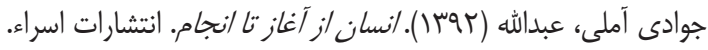

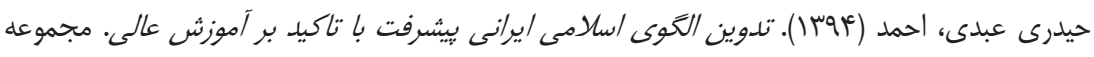

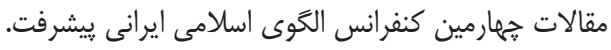

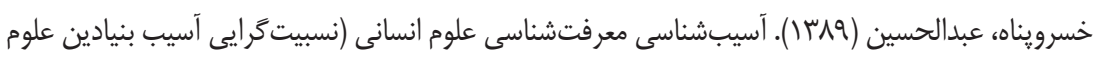

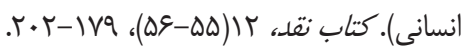

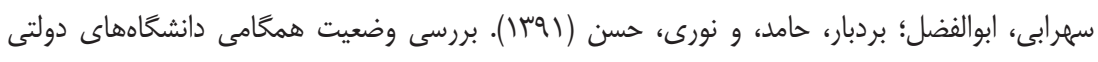

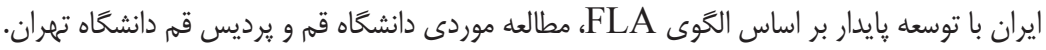

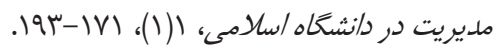

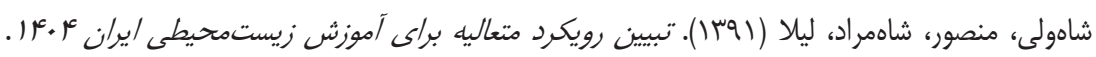

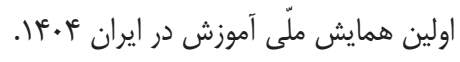

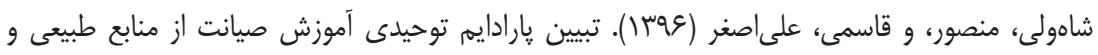

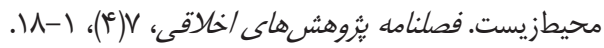

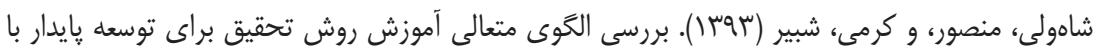

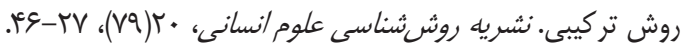

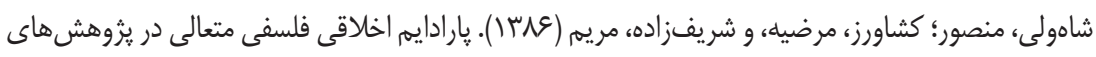




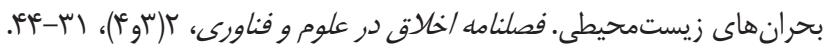

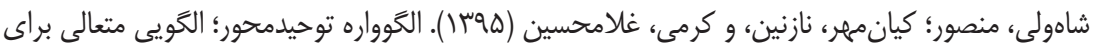

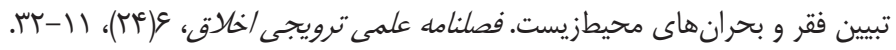

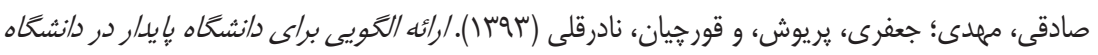

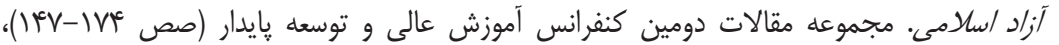

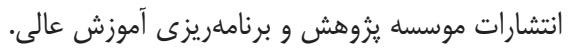

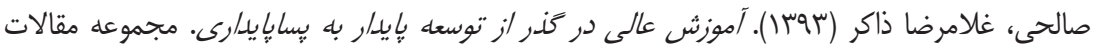

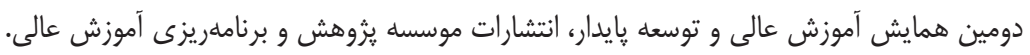

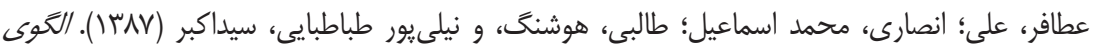

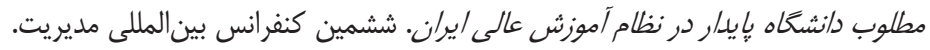

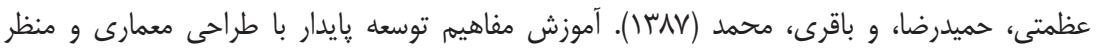

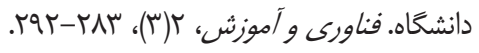

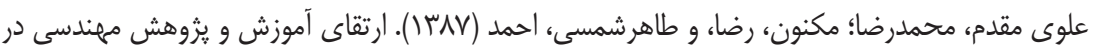

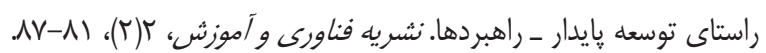

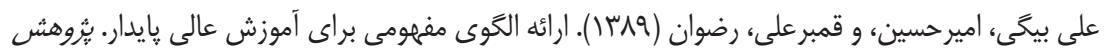

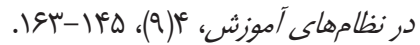

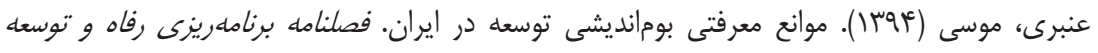

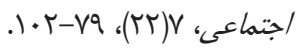

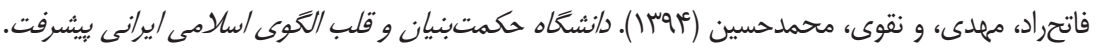

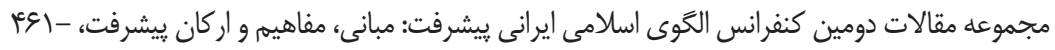
وسז.

فراستخواه، مقصود (1) (1)). بررسى الخوى تعاملات آموزش عالى و دانشگاه با ساير نظامهاى توليد و

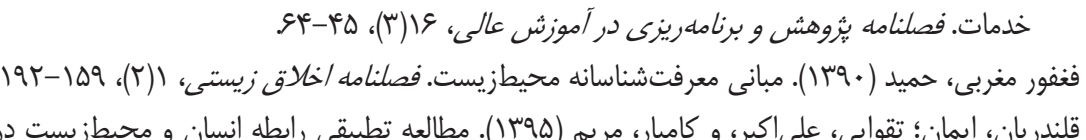

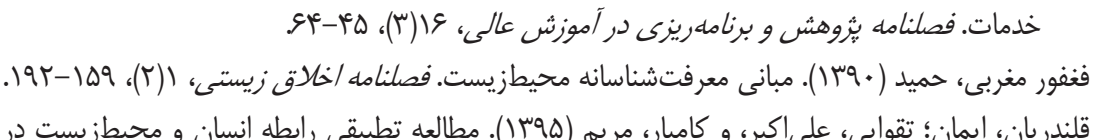
कर

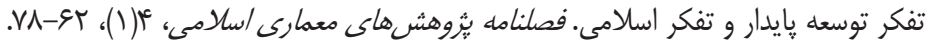

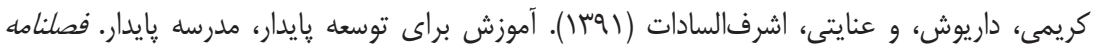

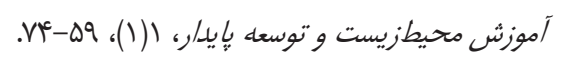

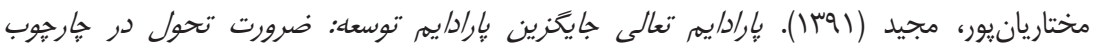

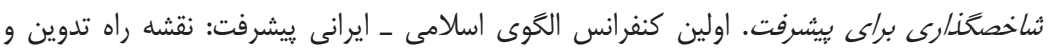

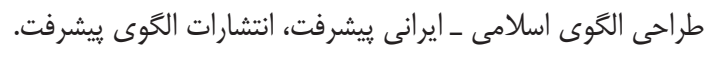

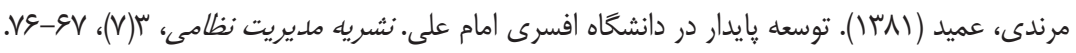
مطקرى، مرتضى (^عسب). انسان كامل. انتشارات صدرا. 


$$
\begin{aligned}
& \text { مطهرىنزاد، سيدمجيد؛ همايون، محمدهادى، و حاتمى، محمدرضا (عاوس(). درآمدى بر تبارشناسى موانع }
\end{aligned}
$$

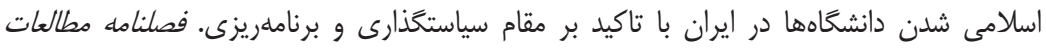

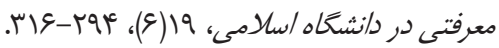

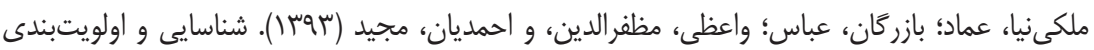

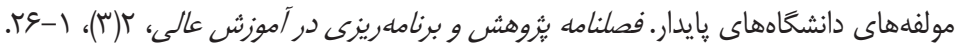

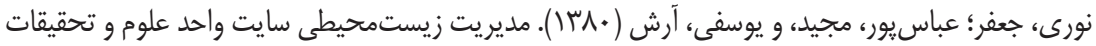

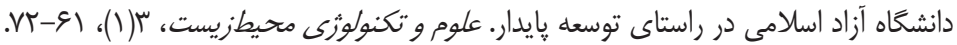

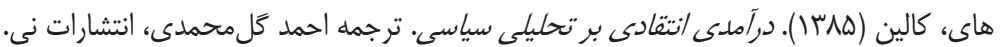

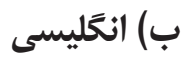

Aguirre, R. T., \& Bolton, K. W. (2014). Qualitative Interpretive Meta-Synthesis in Social Work Research: Uncharted Territory. Journal of Social Work, 14(3), 279-294.

Alexander, V. G. (2015). Development and Validation of the Critical Thinking about Sustainability Scale. (Doctor of Philosophy), Purdue University.

Bergdahl, E. (2019). Is Meta-Synthesis Turning Rich Descriptions Into Thin Reductions? A Criticism of Meta-Aggregation as a Form of Qualitative Synthesis. Nursing Inquiry, 26(1), 1-8.

Calder, W., \& Dautremont-Smith, J. (2009). Higher Education: More and More Laboratories for Inventing a Sustainable Future. Agenda for a Sustainable America, 93-107.

Clark, W. C., \& Dickson, N. M. (2003). Sustainability Science: The Emerging Research Program. Proceedings of the National Academy of Sciences, 100(14), 8059-8061.

Finfgeld-Connett, D. (2006). Meta-Synthesis of Presence in Nursing. Journal of Advanced Nursing, 55(6), 708-714.

Giroux, H. A. (2017). Neoliberalism's War against Higher Education and the Role of Public Intellectuals. The Future of University Education (pp. 185-206): Springer.

Godemann, J., Bebbington, J., Herzig, C., \& Moon, J. (2014). Higher Education and Sustainable Development. Accounting, Auditing \& Accountability Journal, 27(2), 218-233.

Lozano, R., Ceulemans, K., Alonso-Almeida, M., Huisingh, D., Lozano, F. J., Waas, T., ... Hugé, J. (2015). A Review of Commitment and Implementation of Sustainable Development in Higher Education: Results from a Worldwide Survey. Journal of Cleaner Production, 108(1), 1-18. 
Lozano, R., Lukman, R., Lozano, F. J., Huisingh, D., \& Lambrechts, W. (2013). Declarations for Sustainability in Higher Education: Becoming Better Leaders, Through Addressing the University System. Journal of Cleaner Production, 48(1), 10-19.

Petratos, P., \& Damaskou, E. (2015). Management Strategies for Sustainability Education, Planning, Design, Energy Conservation in California Higher Education. International Journal of Sustainability in Higher Education, 16(4), 576-603.

Sandelowski, M. (2008). Reading, Writing and Systematic Review. Journal of Advanced Nursing, 64(1), 104-110.

Sandelowski, M., \& Barroso, J. (2007). Handbook for Synthesizing Qualitative Research. Springer Publishing Company.

Shiel, C., Leal Filho, W., do Paço, A., \& Brandli, L. (2016). Evaluating the Engagement of Universities in Capacity Building for Sustainable Development in Local Communities. Evaluation and Program Planning, 54(1), 123-134.

Shriberg, M. (2002). Institutional Assessment Tools for Sustainability in Higher Education: Strengths, Weaknesses, and Implications for Practice and Theory. Higher Education Policy, 15(2), 153-167.

Timulak, L. (2009). Meta-Analysis of Qualitative Studies: A Tool for Reviewing Qualitative Research Findings in Psychotherapy. Psychotherapy Research, 19(4-5), 591-600.

UNESCO. (2002). Education for Sustainability from Rio to Johannesburg: Lessons Learnt from a Decade of Commitment: UNESCO Paris.

UNESCO. (2007). The UN Decade for Education for Sustainable Development (DESD 2005-2014): The First Two Years, UNESCO, Paris.

Zawadzki, M. (2017). "The Last in the Food Chain": Dignity of Polish Junior Academics and Doctoral Candidates in the Face of Performance Management. The Future of University Education (pp. 63-84): Springer.

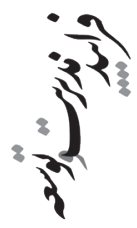


جدول ابٍ: تعدادى از منابع داخلى براى تحليل فراتر كيب

\begin{tabular}{|c|c|c|}
\hline ارائه الكويى براى دانشخاه پِايدار در دانشگاه آزاد اسلامى & صادقى و همكاران (rar) & 1 \\
\hline الحَويى براى تلفيق پِيدارى در آموزش عالى كشاورزى & 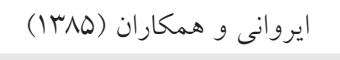 & r \\
\hline شناسايى و اولويتبندى مولفههاى دانشخاه بايدار & ملكىنيا و همكاران (rar| & r \\
\hline ارائه الكوى مفهومى براى آموزش عالى بايدار & 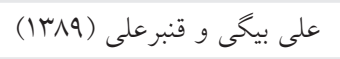 & r \\
\hline 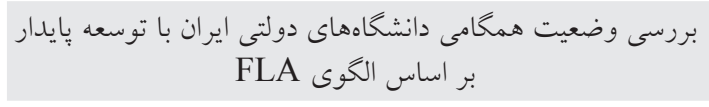 & 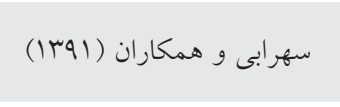 & 0 \\
\hline دانشگاه بِايدار در دانشگاه افسرى امام على(ع) & 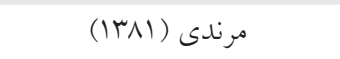 & 4 \\
\hline ارتقاى آموزش و يززوهش مهندسى در راستاى توسعه يايدار - & علوى مقدم و همكاران (TIVV) & V \\
\hline آموزش مفاهيم توسعه بايدار با طراحى معمارى و منظر دانشگاه & عظمتى و باقرى (IrAV) & $\wedge$ \\
\hline مديريت زيستمحيطى سايت واحد علوم و تحقيقات دانشگاه آزاد & نورى و همكاران (•^ش|) & 9 \\
\hline نقش دانشخاهها در آموزش توسعه يِيدار & آراسته و اميرى ( آqس||) & 1. \\
\hline نقشى آفرينى دانشخاه در فرايند توسعه پايدار از رهخذر توليد & جاودانى (r Irar) & 11 \\
\hline الكوى مطلوب دانشگاه پايدار در نظام آموزش عالى ايران & عطافر و همكاران (IrNV (1) & ir \\
\hline ارائه مدل مفهومى رابطه بين كيفيت برونداد آموزش عالى و توسعه رويد & 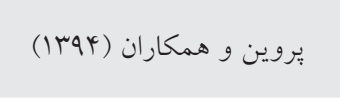 & ir \\
\hline راهبردهاى توسعه آموزش توسعه يايدار در ايران & 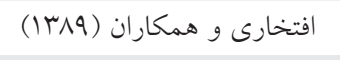 & if \\
\hline آموزش عالى در كذر از توسعه پِايدار به پِسايايدارى & صالحى (r (1) (1) & 10 \\
\hline تدوين الكوى اسلامى ـ ايرانى بيشرفت با تاكيد بر آموزش عالى & 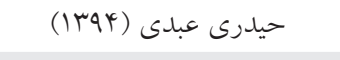 & 19 \\
\hline كاركردهاى دانشگاه از نظر مقام معظم رهبرى در نظام آموزش ائش & باقرى مجد و فلاح فرامرزى & IV \\
\hline 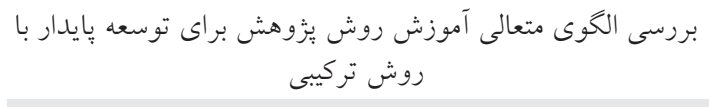 & شاهولى و كرمى (rara) & 11 \\
\hline تبيين رويكرد متعاليه براى آموزش زيستمحيطى ايران \&\&\& & 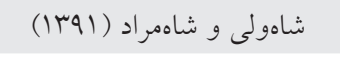 & 1 \\
\hline 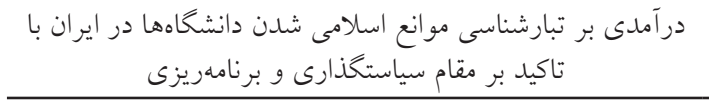 & $(1+9$ & \\
\hline
\end{tabular}

